\title{
Growing into Voting
}

Election Turnout among Young People and Habit Formation

\section{Richard Öhrvall}

SE-581 83 Linköping, Sweden 
At the Faculty of Arts and Sciences at Linköping University, research and doctoral studies are carried out within broad problem areas. Research is organized in interdisciplinary research environments and doctoral studies mainly in graduate schools. Jointly, they publish the series Linköping Studies in Arts and Sciences. This thesis comes from Division of Political Science at the Department of Management and Engineering.

\section{Edition 1:1}

(๔) Richard Öhrvall, 2018

ISBN 978-91-7685-216-3

ISSN 0282-9800

URL http://urn.kb.se/resolve?urn=urn:nbn:se:liu:diva-150169

Published articles have been reprinted with permission from the respective copyright holder.

Typeset using $\mathrm{X}_{\mathrm{G}} \mathrm{T}_{\mathrm{E}} \mathrm{X}$

Printed by LiU-Tryck, Linköping 2018 


\begin{abstract}
This thesis contains an introduction and four essays that together address the issues of turnout and habitual voting. Although voting is less unequal than other forms of political participation, it is still biased in favour of more socially affluent citizens. One way to achieve more equal participation is to increase the general turnout. This is the implication of the 'law of dispersion', formulated by Tingsten in 1937, which states that as turnout increases, participatory equality also increases. In Essay I, co-written with Mikael Persson and Maria Solevid, we revisit Tingsten's law and find new empirical support for it.

One possible path to improving general turnout is the formation of voting habits. It is argued by some scholars that voting is a habit formed early on in life, when young people encounter their first elections after coming of age. It is, however, still a matter of debate as to whether voting is an act of habit. Three of the four essays in this thesis tackle this question in various ways. In Essay II, I study voting among young people who encounter their first election in different social contexts depending on their age, and how these differing contexts affect their propensity to vote in their first and second election. In Essay III, I examine whether experiencing a European Parliament election with a low turnout as a first election affects the likelihood of casting a vote in a subsequent national parliamentary election. In Essay IV, co-written with Sven Oskarsson, we study student mock elections, which constitute the first, albeit hypothetical, election experience for many young people.

The main result is that the first election a young person faces is not as important as has been claimed in previous research. Regardless of whether the initial experience takes place in a context that encourages turnout or the first election encountered is a low-stimulus election that fails to draw crowds to the polls, there is no substantial impact on turnout in subsequent elections. One implication of this finding is that lowering the voting age is not likely to increase voting rates, not even in the longer term.
\end{abstract}





\section{Acknowledgements}

Academia is a competitive world. People compete for positions and research grants, and they are constantly evaluated in various ways. In such an environment, one could expect academics to be reluctant to share their time and extend their help, but my experience is quite the opposite. My statistical training prohibits me from making any generalization from this personal observation-I might be an outlier in the distribution of experiences-but regardless, I am truly grateful for all the generosity I have encountered. As a consequence, I have many people to thank.

First, I would like to thank my three excellent supervisors for their continuous support. I am deeply grateful for their counsel and encouragement. Elin Wihlborg has given me valuable advice, and has guided me away from administrative pitfalls and towards the completion of this thesis. Gissur Ó. Erlingsson has a distinctive ability to extract the essence of a draft, and to uncover a path to a more relevant and engaging text. His precise recommendations and dark sense of humour have been a lifeline. Sven Oskarsson has brought his extensive knowledge on political participation to the table, and his suggestions have helped to improve the methodological rigour of my work. I would also like to thank Charlotte Fridolfsson, who was one of my supervisors during the first phase of my doctoral studies.

At different points on the path towards completion, various people have read my manuscript and given advice on how to proceed. I would especially like to thank Åsa von Schoultz, Anders Westholm, and Mikael Persson for graciously taking the time to read my drafts. Their comments have made this a far better thesis than it would otherwise have been.

Thanks to my former and current fellow doctoral students at Linköping University: Ida Åberg, Ester Andréasson, Eva Edström-Fors, Mariana Gustafsson, Per-Olof Hansson, Albin Olausson Algotson, Mattias Örnerheim, Carl-Johan Sommar, and Johan Wennström. And thanks also to all my other colleagues at the Division of Political Science, Linköping University.

My time as a doctoral student has been a time of commuting back forth to the city of Linköping. Over the years, I have developed a somewhat strained relationship with Sweden's railways. I am truly grateful to Amar Bose and his colleagues for developing noise cancelling headphones. In my book, that is one of the greatest inventions of our time. With headphones on-and in the soothing company of great artists such as Poppy Ackroyd, Ólafur Arnalds, Brian Eno, Nils Frahm, and Ryuichi Sakamoto-I have man- 
aged to survive, in spite of an endless stream of delays and a few more train breakdowns than is bearable.

Fortunately, I have not taken the train to Linköping every day. My deepest thanks to Magnus Henrekson and Henrik Jordahl for letting me spend part of my time at the Research Institute of Industrial Economics (IFN) in Stockholm. It is a wonderful academic environment full of sharp minds, and I am grateful for having been invited into it. I would also like to thank all my colleagues at IFN, in particular Niclas Berggren, Andreas Bergh, and Therese Nilsson.

Special gratitude goes out to my bosses and colleagues at Statistics Sweden. The former for giving me time off to do research, the latter for still remembering even though I have been away for quite some time now.

During my time doing research, I have collaborated with many people in academia, and I would like to thank them all. Apart from those mentioned above, this includes: Hanna Bäck, Katarina Barrling, Stefan Dahlberg, Günther Fink, Mattias Fogelgren, Sören Holmberg, Jonas Linde, Karl-Oskar Lindgren, Karl Loxbo, Måns Magnusson, David Mimno, Fredrik Olsson, Henrik Oscarsson, Mats Sjölin, Maria Solevid, Anders Sundell, Anna Thomasson, Kåre Vernby, and Emanuel Wittberg.

Finally, on a more personal note, to my family and friends: thank you for your support and for not asking too often about when I will be done. And I am sorry for being a bit too distracted and preoccupied lately-I hope I soon will be able to shake the dust of my wings. And closest to my heart, to Paula: always, for everything.

Midsommarkransen, September 2018 


\section{List of Essays}

This thesis is based on the following essays, which are referred to in the text by their Roman numerals.

I Persson, Mikael, Maria Solevid, and Richard Öhrvall (2013). "Voter Turnout and Political Equality: Testing the 'Law of Dispersion' in a Swedish Natural Experiment”. In: Politics 33.3, pp. 172-184.

II Öhrvall, Richard (2018). "Groving into Voting: The First Election Experience and Habit Formation". Unpublished manuscript.

III Öhrvall, Richard (2018). "First Time Fades Away: Effects of European Parliament Elections on National Turnout". Unpublished manuscript.

IV Öhrvall, Richard and Sven Oskarsson (2018). "Practice Makes Voters? Effects of Student Mock Elections on Turnout". Unpublished manuscript. 


\section{Contents}

$\begin{array}{ll}\text { Abstract } & \text { iii }\end{array}$

Acknowledgements $\quad$ v

List of Essays

$\begin{array}{ll}\text { Contents } & \text { ix }\end{array}$

$\begin{array}{ll}\text { List of Figures } & \mathbf{x}\end{array}$

Introduction $\quad 1$

Theoretical approaches to voter turnout $\ldots \ldots \ldots \ldots \ldots$

Findings in previous research . . . . . . . . . . . . . . 15

The Swedish electoral setting . . . . . . . . . . . . . . . . . . . 23

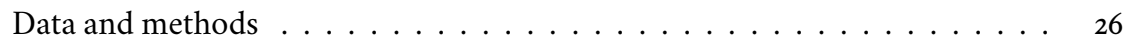

Results .......................... 31

Implications of the findings . . . . . . . . . . . . 4 4 o

$\begin{array}{ll}\text { Bibliography } & 45\end{array}$

$\begin{array}{ll}\text { Essay I } & 57\end{array}$

$\begin{array}{ll}\text { Essay II } & 73\end{array}$

$\begin{array}{ll}\text { Essay III } & 99\end{array}$

$\begin{array}{ll}\text { Essay IV } & 119\end{array}$ 


\section{List of Figures}

1 Turnout in Sweden, $1973-2014 \ldots \ldots \ldots \ldots \ldots \ldots$. . . . . . . . . 24

2 Turnout in EU countries in the 2014 EP election and the parliamentary election immediately prior to that . . . . . . . . . . 26 


\section{Introduction}

Elections are at the heart of democracy. By casting votes, citizens give voice to their preferences and decide who will hold public office. Not all citizens, however, use this opportunity to influence politics, and those who do cast a vote are not a random sample of the electorate. There is ample evidence that voters tend to have higher incomes, greater wealth and better education than non-voters (e.g. Verba and Nie 1972; Wolfinger and Rosenstone 1980; Verba, Schlozman, and Brady 1995; Leighley and Nagler 2014; Öhrvall 2015). This inequality in turnout could lead to election outcomes that do not represent the electorate's preferences and to policy outcomes that are biased towards those who participate.

One way to achieve more equal participation is to increase the general turnout. That is at least the implication of the 'law of dispersion' formulated by Tingsten in 1937, which states that as turnout increases, participatory equality also increases (Tingsten 1937, p. 230). If the law holds, it is not necessary to mobilise specific groups with low turnout in order to improve political equality; as long as general turnout increases, participation will become more equal. One of the essays included in this thesis revisits Tingsten's law, and finds support for it.

Increasing turnout may not, however, be an easy task. Even though there has been an abundance of research focusing on voter turnout, many questions remain about why some people vote and others do not. As noted by Blais (2007), the more research that is devoted to studying turnout, the more complex it appears. Nevertheless, progress has been made and some pieces of the puzzle have been found. One consistent finding in previous research is that voting in one election is a potent predictor for turnout in subsequent elections (e.g. Brody and Sniderman 1977). This is not surprising since some individual characteristics that correlate with voting-such as parental background and 
educational attainment-are time-invariant or at least fairly stable over time. It is likely that an individual with characteristics that tend to promote turnout will have the same characteristics when the next election comes around a few years later. Nevertheless, an increasing number of scholars have argued that the very act of voting is self-reinforcing and that voting should therefore be seen as a habit that can be acquired (e.g. Plutzer 2002; Gerber, Green, and Shachar 2003; Denny and Doyle 2009; Aldrich, Montgomery, and Wood 2011). This concept of habit entails that if two individuals who have identical characteristics, including their previous voting history, should haphazardly make different decisions as to whether or not to vote on election day, then the one who votes will be more likely to vote in a subsequent election than the one who abstains.

In this field of research, the initial level of turnout among young people is of crucial importance (e.g. Plutzer 2002; Franklin 2004). Those voting for the first time after coming of age could form a habit of either voting or abstaining. Whether the first election encountered by a young person is an election that draws many to the polls or a lowstimulus election could therefore have long-term consequences. It is also, according to this line of reasoning, easier to persuade young people to cast a vote since they have not yet acquired a habit of voting or abstaining. It should be noted, however, that this is an emerging field within political science and not all results point in the same direction. Some studies have found that voting in one election has a positive effect on the probability of voting in subsequent elections (e.g. Gerber, Green, and Shachar 2003; Cutts, Fieldhouse, and John 2009; Coppock and Green 2016), but the generalisability of the results has been questioned (e.g. Meredith 2009). There is also research that has failed to find support for the idea of voting being an act of habit (Bergh 2013; Gäbler, Potrafke, and Rösel 2017; Bechtel, Hangartner, and Schmid 2018).

In this thesis, I aim to bring new evidence to this debate. My main purpose is to investigate whether voting is a habit and if the first election is as important for future turnout as some scholars have argued. By also studying the link between turnout and participatory equality, the thesis contributes to the discussion on whether get-out-thevote (GOTV) efforts and electoral reforms designed to mobilise young people are an effective way to increase equality in voting.

Since the 1980s, voter turnout has declined in a wide range of advanced democracies (Blais 2000; Franklin 2004; Blais and Rubenson 2013), and studies have found that this decline in turnout has been especially pronounced among the young (e.g. Smets 2012). If the initial turnout among young people has long-term implications, the question of what brings them to the polls becomes crucial. Much of the previous research on voter turnout has been focused on the individual and their characteristics. This research has emphasised that political participation is related to socio-economic resources, but also to engagement and mobilisation (e.g. Verba, Schlozman, and Brady 1995). In recent years, however, some scholars have put more emphasis on the social logic of voting (e.g. Sinclair 2012; Rolfe 2013). This strand of research stresses the importance of an individual's social networks. For many young people, the family constitutes an important social network that can promote voting, but voting can also be promoted by friends, other students at school, colleagues at work and fellow members of different types of social groups (e.g. Verba, Schlozman, and Brady 1995; Bhatti and Hansen 2012b). 
The importance of different social networks varies over an individual's lifetime. With a voting age set at 18 , as it is in most countries, young adults usually encounter their first election when they are between 18 and 21 years of age. This is a time when many leave school and the family nest to start a life on their own. Since this a disruptive stage in a young person's life, Franklin (2004, pp. 63-66) argues that 18 is a particularly ill-suited voting age. In fact, he takes the argument further and claims that the decline in voter turnout seen in most old democracies over recent decades is, to a large extent, due to the lowering of the voting age to 18 in the 1960s and 1970s (Franklin 2004, pp. 190191, 213-214). This claim is based on the assumption that voting is a habit that is formed by the first elections a young person encounters, and that abstention at the first election could lead to detrimental long-term effects on voter turnout. Franklin therefore recommends that the voting age should be lowered (Franklin 2004, p. 213).

In many Western democracies, the voting age has been lowered on several occasions during the 2oth century, and it is a topic that is now back on the political agenda. In 2007, Austria lowered the general voting age to 16 (Wagner, Johann, and Kritzinger 2012). No other European country has so far followed suit, but some countries have lowered the voting age in local elections and others have experimented with similar reforms (Bergh 2013). In a number of additional countries, the issue has been investigated and debated (Wagner, Johann, and Kritzinger 2012; McAllister 2014; Zeglovits and Aichholzer 2014), and the European Parliament (EP) (2015/2035(INL)) has recommended that, for elections to the EP, member states harmonise the voting age at 16.

Depending on their birthdate and the electoral cycle, young people face their first election at different ages and presumably in varied social contexts. Those who are 18 are likely to be still living with their parents and attending school, while those who are slightly older will have entered a more disruptive phase of life. If the first election is of such crucial importance, as claimed by Franklin (2004), then lowering the voting age from 18 might help to increase turnout, since it would mean that most young people would be exposed to their first election while they are still in school and living with their family.

The date on which a person is born also affects what type of election they will experience first. Most countries have different types of elections with varying election cycles. This includes national elections characterised by high salience and turnout and local elections that receive less attention and draw fewer to the polls. The latter are often labelled second-order elections. For countries that are members of the European Union, elections to the EP might also be categorised as second-order elections (Reif and Schmitt 1980; Hix and Marsh 2011). It has been argued by Franklin and Hobolt (2011) that young people whose first election is an EP election are less likely to vote in subsequent elections to the EP or national parliaments because the initial experience instils a habit of abstention in some. In their opinion, the low voting rates in EP elections have therefore had a harmful effect on turnout in national elections within the EU member states.

If voting is a habit largely formed at a young person's first election, then it could explain the declining turnout within the EU. As indicated above, habitual voting would also have other implications. It could be a rationale for lowering the voting age, since 
such a reform would give more young adults the opportunity to vote for the first time in a context that promotes turnout and thereby increases the probability of forming a habit of voting. It would also be a reason to focus mobilising campaigns on young adults, since such efforts might have a positive effect on turnout not only in an upcoming election but also in many elections that follow, through the forming of a voting habit. If a higher turnout also means a more equal turnout, such reforms and campaigns could also lead to a higher degree of political equality. This line of reasoning is, however, based on some crucial assumptions-most notably that voting is an act of habit-and previous research in this regard has not been conclusive. In this thesis, I examine those assumptions. Three of the four essays contained in this thesis address in different ways how a first election experience affects future turnout. The remaining essay, Essay I, is focused on the link between voter turnout and participatory equality. In all the essays, the analyses are based on statistical methods and Swedish register data of very high quality, with validated information on turnout and no nonresponse.

In Essay I, co-written with Mikael Persson and Maria Solevid, we revisit the aforementioned 'law of dispersion' formulated by Tingsten (1937), which states that as turnout increases, participatory equality also increases. Even if this law has been influential on the literature on turnout (e.g. Lijphart 1997; Hajnal and Trounstine 2005; Finseraas and Vernby 2014), there have been few empirical tests of it and the results have been inconclusive (Sinnott and Achen 2008). We bring new evidence from a study of turnout in the 2010 election to Västra Götaland County Council in Sweden and a rerun election to the same county council in 2011. In the re-run election, voter turnout plummeted from 81 to 44 per cent, and this led to greater inequality of participation across different socio-economic groups. In other words, we found clear support for Tingsten's law.

That higher turnout leads to more equal participation implies that reforms and GOTV efforts increasing general turnout will also improve political equality. If voting is a habit, as suggested by some scholars, such initiatives should be targeting young adults. Three of the essays included in this thesis examine, in various ways, the voting of young people at their first elections after coming of age and whether those early experiences have lasting effects on turnout. In Essay II, I study voting among young people who encounter their first election in different social contexts depending on their age, and how those differing contexts affect their propensity to vote in their first election and in the one that follows. Essay III can be seen as a study of the opposite situation: the consequences of a less stimulating first electoral experience. Here, I examine whether encountering a second-order election with low turnout as the first election after coming of age affects the propensity to vote in a subsequent first-order election. This is done by comparing the turnout in elections to the Swedish national parliament of young adults who turned 18 and became entitled to vote just before or after a previous Swedish EP election.

Finally, Essay IV, co-written with Sven Oskarsson, focuses on mock elections in upper secondary schools. They take place at the time of a general election and can be seen both as a part of the civic education provided by the school system and as a rehearsal for a real election. By giving adolescents the opportunity to practise voting in a social 
context that might foster participation, student mock elections can be seen as an alternative to lowering the voting age. Previous studies have shown that mock elections can increase political efficacy and found a relationship between voting in such events and the stated intention to vote in real elections (Hansen 2017; Borge 2017). There is, however, a fundamental difference between stated intentions and manifested behaviour, and no previous study has examined the effects of mock elections on turnout in real elections.

The main result of this thesis is that the first election a young person encounters is not as important for future turnout as has been claimed in previous research. Regardless of whether the initial experience takes place in a context that fosters turnout or is a low-stimulus election that fails to draw crowds to the polls, it does not have any substantial impact on the likelihood of voting in subsequent elections. This is not to say that efforts to stimulate turnout among young adults are pointless-it is indeed likely that they are more receptive than older members of the electorate-but one should not take for granted that the effects of such efforts will last. Nevertheless, as shown in Essay IV, even well-thought-out mobilising initiatives may fail to increase the likelihood of voting among young adults. These results have some profound implications, as I return to later on.

This introductory chapter is organised as follows: In the next section, I present theoretical models for explaining voter turnout. I provide a more detailed explanation of the relationship between turnout and the social context, and theories about voting as a habit. I also devote part of that section to discussing the definition of voting habit and different mechanisms that might explain how such a habit could be formed. Thereafter, I present an overview of previous research on voter turnout, including the importance of social groups, and how voting in one election might affect turnout in subsequent elections. The focus in that section is mainly on turnout among young people and voting as a habit. Since the data used in the analyses presented in this thesis are from Sweden and refer to Swedish elections, the following section includes a short description of the Swedish electoral system and Swedish turnout. I then give a description of the data and methods used in these analyses. The main results of the essays included in this thesis follow. Finally, the implications of the results are discussed in the concluding section.

\section{Theoretical approaches to voter turnout}

Zuckerman (2005, p. 11) has pointed out that even though the foundational texts on political behaviour had a theoretical framework that included the social logic of politics, they institutionalised a research agenda focused on the individual level of analysis. Those texts provide numerous examples that underline the importance of people's immediate social circumstances for forming their political behaviour. In their seminal book The American Voter from 1960, Campbell et al. ([1960] 1980, p. 76) state that 'Not only does the individual absorb from his primary groups the attitudes that guide his behavior; he often behaves politically as a self-conscious member of these groups, and his perception 
of their preferences can be of great importance for his own voting act.' In another influential book from four years earlier, Voting, Berelson, Lazarsfeld, and McPhee ([1960] 1986, p. 300) claim that 'by the very process of talking to one another, the vague dispositions which people have are crystallized, step by step, into specific attitudes, acts, or votes.'

Yet, despite this emphasis on the social context, the analyses carried out usually revolved around the individual. During the following decades, research into political participation shifted focus away from the social context and towards the characteristics of individuals. Zuckerman (2005, p. 11) puts forward two set of factors that explain this development. The first has to do with the decision to use national sample surveys and the limitation of the statistical techniques available at the time. By design, the samples included separated individuals and any information about their primary groups had to be retrieved through the respondent. As acknowledged by Campbell et al. ([1960] 1980, p. 76), in the absence of any checks such information could be biased by perception distortion. The size of the samples also made it difficult to study subgroups that could be assumed to have a specific social context, e.g. young people living with their parents. Furthermore, the main statistical toolbox available at that time lacked tools for handling more complex data structures. I return to both these aspects later, when I discuss the data and methods employed in the essays that make up this thesis.

The second set of factors put forward by Zuckerman (2005) is related to theory. Some scholars found theories about the role of social groups deterministic and having limited explanatory power, and instead stressed the rationality of the individual (e.g. Key and Munger 1959, pp. 281-82). As Key (1966, p. 7) puts it, 'voters are not fools' and the portrait given by available survey data 'is not one of an electorate straitjacketed by social determinants or moved by subconscious urges'. When it comes to this shift in theory, Downs' seminal book An Economic Theory of Democracy of 1957 is of fundamental importance (Downs 1957). In it, Downs presents the rational choice approach that has been so influential on research on voter turnout.

Downs assumes that citizens act rationally when they make political decisions. A citizen will vote if they conclude that the benefits of voting are greater than the costs; if not, they will abstain. According to Downs, time is the principal cost of voting: time to register, discover which parties are running, deliberate, go to the polls and mark the ballot. Most of these costs might seem trivial, even though some citizens might find it demanding to seek out information about each viable party or candidate and their political platforms. More importantly however, the decision on whether to vote or not depends, according to Downs' model, on the extent of the costs compared to the extent of the benefits. Hence, even if the costs are low, it might still be rational for a citizen to abstain, if the value of the benefits is even lower.

The return a citizen receives from voting is, according to Downs, compounded of a number of factors, but he mentions three that are crucial. The first factor is derived from the value an individual puts on one party (or candidate) winning the election instead of another, i.e. the party differential. The second factor is based on the degree to which they discount the party differential to allow for the influence of other voters: in other words, how likely it is that their vote will be decisive. This is related to the per- 
ception of how close the election will be. These two factors together give the vote value. Since the probability of casting a decisive vote is infinitesimal, the vote value will be tiny and outweighed even by very low voting costs. Together these two factors imply a situation in which almost no one will cast a vote. However, Downs also includes a third factor: the value of voting per se, which is not related to the other two but rather to the individual's desire to see democracy work. As Downs (1957, p. 269) puts it: 'Since the consequences of universal failure to vote are both obvious and disastrous, and since the cost of voting is small, at least some men can rationally be motivated to vote even when their personal gains in the short run are outweighed by their personal costs'. Hence, the perpetuation of democracy can be seen as a reward for voting, and this is labelled by Downs (1957, p. 270) as the long-run participation value. Using this line of arguments, Downs finds an explanation for why it may be rational for some people to vote even if they do not bother to seek out information about the different party platforms; the cost of voting in a way that is not aligned with personal preferences is smaller than the potential ills of not voting at all.

Nevertheless, many researchers have not found this third factor put forward by Downs satisfactory. As Barry (1978) argues, it is not likely that a single vote would be decisive in enabling democracy to continue to work. Riker and Ordeshook (1968) instead propose an expanded model. They build upon the work of Downs (1957) and Tullock (1967), and formulate a more formal model for citizen's decision on whether or not to vote, in which they include benefits received by the individual that are independent of the election outcome.

It could be argued that Downs, with his third factor, also includes benefits that are independent of the election outcome. However, Downs has a narrow definition of rationality that only considers political benefits, while Riker and Ordeshook adopt a broader definition of rationality. They define rationality as being able to order preferences and select the more preferred action over those less preferred. This means that each individual can make calculations about their actions and that those calculations can be understood by others. Using this definition, the benefits reaped by voting do not have to be political. Riker and Ordeshook could thereby include the psychic gratification gained by the individual from the act of voting. This psychic gratification might consist of the satisfaction of complying with the ethics of voting, of affirming allegiance to the political system or of affirming political efficacy, as well as the pleasure of going to the polls, and might be seen as different aspects of the more general concept of civic duty (Blais 2000).

Three additional points made by Riker and Ordeshook (1968) are worth mentioning. Firstly, it is the perceived probability of casting a decisive vote that should be included in the model and not the objective probability. They argue that, for many people, the subjective estimate of the likelihood of casting a decisive vote is higher than is reasonable. Secondly, they conclude that it is likely that, for many citizens, the party differential is much greater than previously assumed. Thirdly, they do not exclude the possibility that some people will act irrationally. Taken together, this could explain why so many people vote, even if at first sight it seems likely that only a few people would do so. 
Nonetheless, the model advocated by Riker and Ordeshook has also attracted criticism. The main critique is related to the inclusion of psychic gratification; if such benefits are included, it could always be argued that a voter will decide to cast a vote because they consider the benefits to outweigh the costs, and the theory thus cannot be falsified (Verba, Schlozman, and Brady 1995; Blais 2000). This risk of falling into a tautological trap was recognised by Downs and it was the reason why he chose a definition of rationality that only included those actions that lead to strict political or economic ends (1957, pp. 275-76).

Even if the social context and the role of groups could be integrated into a rational choice framework, Zuckerman (2005) and others argue that the individual's social circles should have a more profound role in analyses of political participation (e.g. Rogers, Fox, and Gerber 2013). Another strand of the literature has proposed that the research should be expanded in another way-in the temporal dimension. Scholars adhering to this perspective believe voting should be seen as a habitual act and that, if an individual casts a vote in one election, they will, ceteris paribus, be more likely to also vote in a subsequent election (e.g. Plutzer 2002; Gerber, Green, and Shachar 2003). These two expansions-bringing in the social context and the temporal dimension-are discussed further in the remaining parts of this section.

\section{The social context}

It has long been recognised that there is a relationship between socio-economic resources and political participation. In their seminal book Participation in America, Verba and Nie (1972, pp. 125-37) present a model based on the assumption that people with a higher socio-economic status are more likely to develop a civic orientation, such as a concern for politics and feelings of efficacy, that leads to political participation. Verba, Schlozman, and Brady (1995) argue that both the socio-economic model and the rational choice approach have shortcomings as frameworks for analysing political participation. In their view, the socio-economic model has empirical power to predict activity but is theoretically deficient in failing to clarify the link between resources and participation. On the other hand, they find that the rational choice approach is theoretically rich but lacks predictive power and relevance. In line with the critique mentioned above, they argue that, when the rational choice model is extended to include psychic benefits, it becomes almost unfalsifiable and hence loses its analytical bite.

The solution put forward by Verba, Schlozman, and Brady (1995) is what they call the Civic Voluntarism Model. The model focuses on three answers to the question of why some citizens do not participate: because they cannot, because they do not want to, and because nobody asked. In other words, they argue that some people are inactive because they do not have resources, lack engagement, or are situated outside of networks that could mobilise them into political activity. By 'engagement', they mean psychological engagement with politics, for example an interest in political affairs or a sense of efficacy.

An individual's social context can help promote turnout by addressing all three aspects of participation included in the Civic Voluntarism Model. Other individuals 
within a social network can provide information that reduce the cost of voting, for example by providing details on the party platforms or by explaining the electoral process and how to cast a vote. They can also stimulate interest in political affairs through discussions and they can mobilise by encouraging participation. Within a social network, individuals can be pressured to participate (Rolfe 2013). Such pressure can be explicit, but also subtle. As discussed by Rogers, Fox, and Gerber (2013), the basic need to belong can influence people to act in accordance with how they expect others to behave (see also Tajfel 1974). If they perceive that voting is part of a social norm within a group they belong to, they may conform to this norm regardless of their political interest.

Social networks can also affect the impact of mobilising activities undertaken by other actors. Candidates, activists, parties and other organisations may all mobilise people to participate in elections. Rosenstone and Hansen (1993, pp. 25-30) distinguish two types of mobilisation: direct and indirect mobilisation. Direct mobilisation includes all activities whereby different political actors contact citizens and encourage them to take action, for example through meetings and rallies or by GOTV campaigns. The latter can include non-personal contact, such as letters and flyers, but also more personal contact, such as phone calls and door-to-door canvassing within the constituency. Mobilising activities can reach beyond the individuals contacted directly since those individuals are embedded in social networks. Political information can be spread through those networks, and a mobilised individual can affect the behaviour of other members that belong to the same social group. Social networks can thus convert direct mobilisation into indirect mobilisation. This amplifies the effect and reduces the cost of mobilising activities.

Although social networks in general can play an important role in stimulating political participation, specific types of social networks are likely to be more important for some people than others. The importance of different networks might also be expected to change over the course of a person's life. One social group that is often mentioned in the literature, and which is considered to have an important role for most people, is the family (e.g. Verba, Schlozman, and Brady 1995, pp. 416-27; Brady, Schlozman, and Verba 2015). This is especially true for young people growing up, but the family can also have long-term effects on political participation.

Verba, Burns, and Schlozman (2003) discuss two mechanisms by which parents might influence the political participation of their children. Firstly, parents with socioeconomic advantages, such as education or income, pass on those socio-economic advantages to their children, and these are then translated into political activity. Secondly, parents may expose their children to political discussion and other stimuli that promote later political engagement. Since people who are more socio-economically advantaged tend to be more interested in politics, these two mechanisms are likely to be correlated. This way in which participation is transferred over generations has been labelled by some as status transmission theory (Gidengil, Wass, and Valaste 2016). The suggested mechanisms are closely related to the first two aspects of the Civic Voluntarism Model-resources and engagement. The third aspect of the model is also likely to be relevant in this context: it is plausible that parents can mobilise their children by encouraging them to vote, especially if they all are living under the same roof at the time 
of the election. Another mechanism by which the political participation of the parents can be transferred to their children is what is sometimes called social learning theory (Gidengil, Wass, and Valaste 2016). This theory stresses the child's observational learning and the modelling of behaviour on the parental example (Westholm 1999; Jennings, Stoker, and Bowers 2009). This can be seen as adaptation to the social norm of a group, albeit to a very small and specific group, i.e. the family.

Another important social context and potential agent of political socialisation is the school. Education is a fundamental socio-economic resource whose role is often stressed in research on political participation (e.g. Campbell et al. [1960] 1980; Wolfinger and Rosenstone 1980; Verba, Schlozman, and Brady 1995). The underlying assumption is that schools will impart political information and various skills, which will in turn facilitate political learning and thereby increase interest in political affairs and reduce the cost of voting (Wolfinger and Rosenstone 1980). Education thus has the potential to reduce inequality in participation that stems from different family backgrounds. Some scholars have, however, questioned whether the relationship between educational attainment and participation is causal, and they instead argue that it might be a proxy for pre-existing characteristics (Berinsky and Lenz 2011; Persson 2014). If that is the case, education might not be a tool for levelling the playing field as has been suggested in previous literature. Nonetheless, schools can provide a social context that can mobilise at the time of election. Teachers can discuss an upcoming election and address the political issues at stake, thereby increasing the students' political interest, and classmates can form social groups that stimulate the political participation of their members.

There are other noteworthy social contexts that might affect political participation. After leaving school, most people find an occupation. The workplace then becomes a social context in which much of the day is spent, and the co-workers may form a social group that might influence political participation (Rosenstone and Hansen 1993, pp. 3132). Another important event in life for many is finding a spouse or partner; they may then form a relationship that can be seen as an intimate social group, which might affect political behaviour (Stoker and Jennings 1995). Friends and neighbours are other social groups that could potentially have an effect on the likelihood of voting (Huckfeldt 1979; Huckfeldt and Sprague 1992). Finally, in any discussion of social contexts that may affect voter turnout, we should also mention organisations. Political organisations can encourage an interest in politics and mobilise their members at the time of elections. It is, however, likely that people who join such organisations already have an interest in politics or at least in certain policy issues, but becoming a member can help to maintain, or even further develop, that interest. Non-political organisations such as sports or religious organisations can also promote turnout through the same mechanisms as other social networks (Verba and Nie 1972, pp. 174-208).

Expanding the analysis from the individual to take in their social context too shows that there are numerous social groups that could potentially affect a person's decision to vote or abstain. The influence of those groups might be direct and explicit or indirect and subtle. Individuals who share the same characteristics but are embedded in divergent social contexts might therefore have different propensities for voting. Such differences might exist not only between different individuals but also-as I will return 
to later-at different points in time over the course of an individual's life. When studying voter turnout, therefore, there is justification for bringing in both the social logic and the temporal dimension.

\section{Persistence and habitual voting}

Many of the factors that are assumed to be associated with turnout are likely to be fairly stable over time. This includes socio-economic resources, psychological traits, attitudes, and social influences (e.g. Verba and Nie 1972; Wolfinger and Rosenstone 1980; Coppock and Green 2016). If a person votes in one election, we expect them to vote in the next election too. A growing number of scholars have taken the argument further and claim that the very act of voting is self-reinforcing (e.g. Plutzer 2002; Gerber, Green, and Shachar 2003; Dinas 2012). This idea is not new; Campbell et al. ([1960] 1980, p. 92), for example, expressed it as follows: 'It is plausible to think of voting as a type of conduct that is somewhat habitual and to suppose that as the individual develops a general orientation towards politics he comes to incorporate either voting or non-voting as part of his normal behavior.'

The idea of habitual voting has gained more attention in recent research. Nevertheless, in this strand of literature, the concept of voting habit is defined in various ways and sometimes not at all. Most researchers use the same definition as Denny and Doyle (2009), who state that 'Habits occur when, other things being equal, the decision to vote is dependent on whether the individual did so in the previous election' (e.g. Gerber, Green, and Shachar 2003; Cutts, Fieldhouse, and John 2009; Coppock and Green 2016). I also adhere to this definition. It should be noted that the 'other things being equal' element is a crucial part of the definition; the claim is not simply that an individual's voting propensity persists over time, but that the decision to vote or abstain in one election has a causal effect on the likelihood of voting in subsequent elections.

As I argue below, this definition includes some possible mechanisms that are not commonly described as habits. It could therefore be argued that another label would be preferable. Green and Shachar (2000) use the term consuetude since, as they put it, '[c]onsuetude is conventionally defined as habit or custom but lacks the unwanted connotations of those terms.' However, in later research Green has abandoned 'consuetude' in favour of 'habit' (e.g. Gerber, Green, and Shachar 2003; Coppock and Green 2016). There is also a long tradition of using the label of 'habit' in research on voter turnout going back at least to Gosnell (1927), and today the label is ubiquitous. In order not to cause confusion, I have therefore decided to adhere to this convention.

It is still worth mentioning that Aldrich, Montgomery, and Wood (2011) use a narrower definition where '[h]abit involves repetition of a response under similar conditions so that the response becomes automatically activated when those conditions occur.' This is a definition of habit that resembles the way the term is used in social psychology (see Wood and Neal 2007), but is rarely used by other researchers studying voter turnout. Their argument is that voting becomes automated through repetition. In order to form such a habit, this repetition has to take place in the same context, or at least in a very similar one. A change in context or in the cue associated with elections 
could break the habit, and the individual would then have to make a new, deliberate choice as to whether or not to vote. They do not state how many repetitions they expect are necessary to form a habit of voting. Since elections in many countries take place at least a few years apart, it could take a long time before a person achieves even a handful of repetitions. If different types of elections constitute separate contexts, it would take an even longer time. I therefore find it very unlikely that voting could become an act of habit in this sense, and I do not give this argument any further attention.

In previous research, various other mechanisms have been suggested to explain habitual voting. They are often presented in the form of a list of potential explanations without any detailed discussion of how they differ in nature (e.g. Gerber, Green, and Shachar 2003; Dinas 2012). I argue that these mechanisms can be grouped into three separate categories. In the first category, I place mechanisms associated with costs. This includes mechanisms that are based on the idea that casting a vote in one election reduces the cost of voting in a following election (e.g. Gäbler, Potrafke, and Rösel 2017). For example, a person who has voted before knows the procedure for casting a vote and the location of the polling station. Elections often involve the same parties and their relative political positions are not likely to change fundamentally between elections, so the cost of getting information about what is at stake is probably lower after a first vote. It could also be argued that, given the cost of information, it is rational to make the same voting decision as previously. Downs (1957, p. 85) stated that 'some rational men habitually vote for the same party in every election'. His argument was that an individual can save resources by not analysing all the available information in all elections but rather voting for the same party as previously until something extraordinary reveals that this is no longer a suitable option. The same logic could also be applied to the decision as to whether to vote or not.

In the second category, I put mechanisms related to broad psychological orientations known to influence voter turnout, such as feelings of civic obligation, level of partisanship, or interest in politics. Going to the polls can confirm and reinforce one's self-image as a civic-minded, politically involved citizen, and it can also bring about positive or negative feelings about engaging in the act of voting itself (e.g. Milbrath 1965; Gerber, Green, and Shachar 2003). Voting can also lead to an interest in politics that endures until the following election. This category also includes explanations that are associated with political efficacy. By casting a vote, the individual can become more confident in their ability to participate in the political process.

The third category differs somewhat from the other two. Here, I place mechanisms that are based on changes in how other actors behave depending on whether the individual votes or not. This includes the assumption that voters receive much more attention from parties, candidates, and activists than do non-voters (see Gerber, Green, and Shachar 2003). Political campaigns can retrieve information about who voted in the previous election and target their efforts towards them. This type of explanation emphasises that if an individual votes, the likelihood of their being approached by different mobilising actors increases. However, it is also possible to conceive that parties might choose to target non-voters on the assumption that more votes are potentially 
to be gained among them. These mechanisms of course hinge on information about earlier voting behaviour being publicly available.

Any factor that causes an individual to vote instead of abstain could, through the above-mentioned mechanisms, have downstream effects on turnout in subsequent elections. This factor might, for example, be a social context that promotes voting or exposure to a GOTV campaign. It is worth underlining that habitual voting thereby implies that such factors can have an effect greater than the increase in turnout in an upcoming election, since it could also help increase future turnout by instilling a habit of voting. This could be seen as a multiplier effect of mobilising efforts.

On the other hand, a factor that decreases turnout in one election might also have lasting effects through what might then be labelled habitual abstention. It is, nonetheless, likely that not all the above-mentioned mechanisms are at play in that situation. Abstention might affect an individual's psychological orientations, but the effect of not taking part in an election might be different to the effect of going to the polls, especially for an individual who does not pay any attention to political campaigns and elections. Furthermore, even if voting reduces the cost of future turnout, it is unlikely that not voting increases the cost, at least not by the same amount. An individual who has not voted before should not face an increase in the cost of voting in future elections if they decide to abstain. If they have voted before, they will still be familiar with the voting procedure even if they decide not to cast a vote in one election.

This means that, even if voting is a habit, there are several reasons to assume that a negative impact on voting in one election might not have the same effect on future turnout as a positive impact. It could also be argued that non-voting is likely to be a weaker habit than voting. Non-voters have to learn about the electoral process and obtain some degree of political knowledge before casting a vote, but once they have passed this threshold they possess this information and it provides stability. This is a view held by Plutzer (2002), who sees voter turnout as developmental and characterised by modest inertia for non-voters and strong inertia for voters.

A different position is advanced by Franklin (2004, p. 204), who states that the first three elections a young person experiences are fundamental to forming a habit of voting or abstaining. This is based on the assumption that people get set in their ways and after a few elections become immunised against change in voting behaviour (Franklin 2004, pp. 21-22, 204). This could be included in the third category of mechanisms discussed above. That it is just the first three elections that are of importance is not based on any theoretical argument but rather on previous empirical studies carried out by Butler and Stokes ([1971] 1974) and Plutzer (2002). However, those analyses do not support such a hypothesis: Butler and Stokes ([1971] 1974, pp. 48-58) do not study turnout, they examine party choice, and they do not claim that party choices become fixed after the three first elections even if they do find that early, formative influences carry over into later voting. Plutzer (2002) emphasises the first election and argues that non-voters thereafter become voters over time, since non-voting is a weaker habit. It should also be mentioned that neither of those two studies are based on data that makes it possible to make any definitive assertion as to whether the three first elections a young person encounters form a voting habit that is then sustained over subsequent elections. 
Nevertheless, there are reasons to assume that the first election a young person encounters is of particular importance. If the decision to vote or abstain is in some way affected by previous election behaviour, the first election is the one occasion when this is definitely not so since the voting record at that time is blank. Many researchers have therefore put an emphasis on that first election after coming of age (e.g. Plutzer 2002; Smets 2016; Bechtel, Hangartner, and Schmid 2018). Plutzer (2002) argues that once a person has voted, they have gained knowledge about how to vote and obtained at least some political information, and they have probably received some positive reinforcement from friends, family, or co-workers. In Plutzer's view, by voting they become habitual voters, and even if that voting habit can be interrupted by major major life disruptions it will only be temporarily. Although Franklin states that the three first elections are fundamental to the forming of voting habits, he is also, at least implicitly, emphasising the first election. This is because he argues both that the lowering of the voting age to 18 in most old democracies in the 1960s and 1970s led to a decline in voter turnout (Franklin 2004, pp. 190-91, 213-214) and that young people whose first election is a low-stimulus election are less likely to vote in subsequent elections (Franklin and Hobolt 2011). Both these hypotheses are based on the assumption that the first election after coming of age is of vital importance for future turnout. In any case, if we expect a mobilising or demobilising factor in one election to have long-term effects on turnout through habit formation, it is more likely for this to occur among young people than among older people who have experienced elections before. This underlines the value of studying turnout among young people when trying to find out whether or not voting is an act of habit.

\section{Turnout and life-cycle transitions}

As discussed above, the social context can help to promote voter turnout in various ways. The contexts that are influential in this regard are likely to vary not only between individuals but also over the course of an individual's life. If the first election experience helps to form a habit of voting or abstaining, the social context at that time becomes vital. With the voting age set at 18 , as is the case in most democracies, young people face their first election while in a disruptive phase (Highton and Wolfinger 2001; Franklin 2004). It is a time in life when many of them are leaving school and the family nest to start a new life and look for a job or pursue higher education. This can lead them to relocate to a new town, leaving friends and family behind, and thereby weakening important social ties. On the other hand, the change may also help them find new friends and co-workers, and in that way form new social networks.

In previous literature, scholars have expected these life-cycle events to dampen turnout among young adults (e.g. Verba and Nie 1972; Wolfinger and Rosenstone 1980; Highton and Wolfinger 2001). However, one aspect not mentioned in this literature is that young people face their first election in very different social contexts depending on their birthdate and when elections take place. This difference is due to the fact that elections in most countries occur a few years apart. The electoral cycle means young people encounter their first election at different ages, and, even if that difference may 
seem small, it can have substantial effects. A person who is 18 at their first election is likely to still be at upper secondary school and living with their parents. If family and school constitute important social groups that can encourage turnout, as proposed in some theories, then 18 -year-olds will be able to cast their first vote in an advantageous context. Those who are a few years older when they encounter their first election will already have left school and are more likely to have left their family home, and they are thereby in a context that is less beneficial for turnout.

If social groups are of the importance that previous literature suggests, we should expect turnout to vary depending on the age of the young adults when they have their first opportunity to vote. Furthermore, if the first election is crucial for forming a habit of voting, as argued by some scholars (e.g. Plutzer 2002; Franklin 2004), we should also expect this difference in turnout to persist over time.

The date a person is born may also have other implications for turnout. In most democracies, different types of elections occur at separate points in time. A person's birthdate therefore also affects the type of election they will face first. National legislative elections tend to generate relatively strong political interest and draw many people to the polls compared to other elections (Blais 2000). National elections are therefore sometimes labelled first-order elections. Second-order elections, on the other hand, include local elections or, in countries that are members of the European Union, elections to the EP (Reif and Schmitt 1980; Hix and Marsh 2011). Depending on when they are born, a young adult's first election experience may be either a low-stimulus election or a more salient election. This will in all likelihood affect their propensity to vote in that election. If the first election is vital for forming a habit, that decision could, then, have long-term consequences.

To summarise, a person's birthdate may have implications for the likelihood of their voting in the first election they encounter, and this might affect the likelihood of them forming a voting habit and could therefore potentially have long-term effects on their future electoral behaviour. In this thesis, I examine whether the data supports these expectations.

\section{Findings in previous research}

Voter turnout has been an active research field for a very long time. Many scholars have devoted time and effort to finding out what drives people to the polls. Still, as Smets and van Ham (2013) put it: 'Despite decades of research aiming to understand what drives citizens to the polls, the jury is still out on what the foundations of micro-level turnout are.' Although the puzzle has not been solved, the numerous studies carried out have discovered many pieces that help to identify the underlying mechanisms.

The focus of this thesis is on turnout among young people and habit formation. As mentioned in the previous section, depending on their birthdate and the electoral cycle, young people will be of different ages and thus embedded in varied social contexts when they encounter their first election, which could affect the likelihood of their voting. If the first election is important for forming a habit of voting, this could in turn also have 
an impact on turnout in subsequent elections. In this section on earlier findings in studies on voter turnout, I therefore emphasise results that address two related aspects. Firstly, I present findings that describe in various ways the relationship between social context and turnout. This includes the impact of both social groups and mobilising activities carried out by different actors. Secondly, I introduce results from the growing field of research on whether voting is a habit.

If voting is a habit and that habit is formed early on, then this could inform what measures might be taken in order to increase turnout. Nevertheless, a central question remains: does it matter how high the turnout in an election is? In Essay I of this thesis, an answer to this question is given through an examination of the relationship between turnout and participatory equality. If turnout is biased in favour of socially affluent people this might affect not only who gets elected but also policy outcomes. This section concludes with a brief overview of what previous studies have found in this regard.

\section{Social networks and mobilisation}

It is well known from previous research that the relationship between age and voter turnout is curve-linear-turnout is lower among young and very old people (e.g. Tingsten 1937; Campbell et al. [1960] 1980; Wolfinger and Rosenstone 1980; Bhatti, Hansen, and Wass 2012). It has, however, recently been discovered that the relationship is not perfectly curve-linear: a striking divergence can be seen among the youngest people. Among the very young, the turnout of those aged 18 is higher than that of their slightly older peers. Between the ages 18 and 20, turnout drops off before gradually increasing again with age. This phenomenon has been observed in Sweden (Öhrvall 2009), Germany (Konzelmann, Wagner, and Rattinger 2012), Finland and Denmark (Bhatti, Hansen, and Wass 2012). This is in line with the theoretical expectation, discussed in the previous section, that 18 -year-olds are more likely to encounter their first election in a more advantageous social context.

Using data from the 2009 local elections in Denmark, Bhatti and Hansen (2012a) found that 18 -year-olds were more likely to live with their parents, and that in turn seemed to have a positive influence on their propensity to vote. That positive influence was dependent on the parents' electoral behaviour; if none of the parents voted, living with them reduced the likelihood of voting. As the young adults left the nest, the influence of their parents' appeared to wear off. It should, however, be noted that the analysis by Bhatti and Hansen (2012a) is based on cross-sectional data, so they were not able follow the individuals over elections and no causal mechanisms were identified.

Verba, Schlozman, and Brady (1995, pp. 458-459) have found evidence of other ways in which parents influence their children's political activity. Their results indicate that both political socialisation and the reproduction of social status are processes by which levels of political participation are maintained over generations (see also Schlozman, Verba, and Brady 2012, pp. 185-98). They see the parents' educational attainment as a crucial factor: parents who are well-educated are more likely to expose their children to politics, and their children tend also to be highly educated and so possess resources and engage with organisations. 
The relationship between socio-economic factors and political participation is wellestablished in the literature (e.g Campbell et al. [1960] 1980; Verba, Schlozman, and Brady 1995). There is comprehensive evidence that participation is not equal: people rich in resources consistently participate to a greater extent than those who have few resources. Studies of the relationship between political participation and socio-economic status usually include variables relating to education, income and occupation (e.g. Verba and Nie 1972). Many studies have found education to be the socio-economic factor that has the strongest correlation with the propensity to vote (Wolfinger and Rosenstone 1980; Blais 2007; Leighley and Nagler 2014). This has given education a central role in research on voter turnout.

Some scholars have seen school as an institution that provides young people with skills that encourage turnout (e.g Rosenstone and Hansen 1993, p. 136). If this is the case, schools could compensate for students' differing socio-economic backgrounds and thereby level the playing field for political participation. Recent studies have, however, questioned whether education has a direct causal effect on political participation (Persson 2014; Berinsky and Lenz 2011). Some argue that education has an indirect effect by sorting people according to different social statuses and contexts (e.g. Rolfe 2013, pp. 125-150; Nie, Junn, and Stehlik-Barry 1996). Others have proposed that education is a proxy for pre-existing characteristics that can affect both social status and political participation (Persson 2015). It might also be that, in the search for population-average effects, researchers have failed to recognise the effects of education within specific subgroups. For example, Lindgren, Oskarsson, and Persson (2017) found that an increase in the length and amount of social science education in Swedish vocational training programmes led to a more equal turnout, by increasing the likelihood to vote among individuals from families with low socio-economic status. In other words, the jury is still out on whether education causes turnout and which mechanisms are at play.

In addition to social science education, schools can arrange other activities that are even more closely related to voting. In many countries, schools arrange mock elections at the time of general elections (Borge 2016). This exposes young people to political information and allows them to practise voting, even if they have not yet come of age. A study by Borge (2017) shows that students who have voted in such mock elections are more likely to state that they will also vote in a future, real election. Since talk is cheap, this does not necessarily mean that they will get out and vote when the next election comes around. The relationship between mock elections and turnout in real elections has not previously been studied, but it is examined in Essay IV of this thesis.

In the literature, a common explanation for the relatively low turnout among young people is that they have various start-up costs; after leaving school many of them will pursue a career or a university degree, which entails a higher degree of mobility (Milbrath 1965, p. 114; Verba and Nie 1972, p. 145). Many studies have shown that residential stability is associated with a higher turnout (e.g. Squire, Wolfinger, and Glass 1987; Highton and Wolfinger 2001). There are some indications that the mechanism behind this is the need to re-register rather than the disruption of social ties, at least in the US (Highton 2000). 
According to life-cycle theories, young people tend to settle down after those mobile and more disruptive years. Many find a job and come to share their days with their co-workers. The results of previous studies on the effect of having an occupation have been mixed: some have found higher turnout among employed (Wolfinger and Rosenstone 1980; Rosenstone and Hansen 1993), while others have found turnout among this group to be lower (Cebula 2017). At this stage in life, many also find a loved one to share their lives with, which is likely to lead to residential stability. Finding a spouse or partner may also lead to a greater likelihood of voting. Past research has identified spouses as an important source of mobilisation (Campbell et al. [1960] 1980; Wolfinger and Rosenstone 1980). Since there is a clear selection mechanism at work when finding a spouse, it is difficult to disentangle any causal effects, but some findings suggest that marriage has a positive effect on turnout in particular among less-educated individuals who find a highly-educated partner (Frödin Gruneau 2018). Other studies have shown that widowed and divorced voters, even after reasonable controls, are less likely to vote than their married counterparts (Wolfinger and Wolfinger 2008). Furthermore, Hobbs, Christakis, and Fowler (2014) matched individuals who had lost their spouse to other individuals who still lived with their spouse, and studied their turnout over time. The immediate effect of losing a spouse was substantial, but they also found that even after turnout rates stabilised, widowed individuals voted to a much lesser extent than they would have done if their spouse had still been living. This could be due to the loss of someone to accompany to the polls. A Danish study based on a digital voter list with a time-stamped turnout record shows that a majority of those who live in households with two or more members go to the polls with another household member (Bhatti, Fieldhouse, and Hansen 2018).

After settling down, people become more rooted in their neighbourhood. Verba and Nie (1972) underline the relevance of the environment in which individuals live, the kinds of organisational structures they are exposed to and the kind of community they live in (see also Huckfeldt 1979). In their empirical analyses, they find that active membership in organisations is associated with more political activity, while inactive membership is not. Not surprisingly, they find that political organisations in particular stimulate political participation, but they also find that membership of non-political organisations correlates with higher participation (see also Putnam, Leonardi, and Nonetti 1993, pp. 163-186; Putnam 2000, pp. 336-344). This is in line with a study by Gerber, Gruber, and Hungerman (2016) that shows church attendance having a causal effect on turnout. The role of non-political organisations is also stressed by Verba, Schlozman, and Brady (1995), who reached the conclusion that such organisations can enhance participation by improving civic skills and by acting as a source of requests for political activity. There are also studies that find people being affected by social norms. Survey experiments indicate that information about whether a person votes directly affects how favourably that person is viewed (Gerber et al. 2016), and field experiments have found people adapting to descriptive social norms (Gerber and Rogers 2009).

Individuals can also be mobilised by actors outside their social network. This is, for example, the purpose of political campaign organisations. Numerous field experiments undertaken as GOTV campaigns have shown that individuals can be mobilised to vote 
(Green and Shachar 2000; Green, Gerber, and Nickerson 2003; Green, McGrath, and Aronow 2013). They show that face-to-face canvassing is more effective in mobilising than phone calls or mailings (Green and Shachar 2000). Phone calls are more effective if conducted in a more social, unhurried manner (Nickerson 2007). Furthermore, a largescale field experiment by Gerber, Green, and Larimer (2008) shows that individuals can be mobilised into voting by social pressure. In the experiment, the treatment group received mail promising to inform both the household and their neighbours at a later date about their turnout in the upcoming election. Turnout was much higher in the treatment group than in the control group that did not receive the mail. This finding further underlines the ability of networks to mobilise individuals through norms and social desirability.

It should, however, be noted that most of these field experiments have been conducted in the US. Experiments with door-to-door canvassing in Europe have had little or no effect (Bhatti et al. 2016; Nyman 2017). Other experiments have been more in line with results from the US. Bhatti et al. (2017b) sent mobile phone text messages to a random sample of young Danes encouraging them to vote. They identified a small, but still significant, effect on turnout. It is worth mentioning that they also identified a spillover effect: other family members were also mobilised by the text messages (Bhatti et al. 2017a). This includes parents, but only in the case of those young people still living with their parents. Other studies of mobilising efforts have also identified spillover effect from the individuals who were contacted to their family members and friends (e.g. Nickerson 2008; Bond et al. 2012; Sinclair 2012).

Taken together, these studies offer ample evidence that social contexts can help promote turnout in elections by distributing information, instilling norms or mobilising. The importance of different contexts is expected to vary between individuals and over the course of a person's life. Findings from previous research also underline how social networks can amplify the impact of mobilisation efforts through indirect effects; individuals with more extensive social networks are more likely to be reached through those networks. Among those young people encountering their first election, someespecially 18-year-olds-are still enrolled in school and live with their parents, and are thereby embedded in social contexts that facilitate voting, while others have left school and the family home and entered a more disruptive phase in life, which could dampen turnout.

\section{Voting over time and habit formation}

One robust finding in previous research is that an individual's turnout tends to be consistent over time (e.g. Brody and Sniderman 1977; Campbell et al. [1960] 1980). This is at least to some extent to be expected since socio-economic resources are potent predictors of turnout and they tend to be fairly stable over the course of an individual's life. Social influences and intrinsic motivation might also be expected to endure over time. There is, however, a growing body of scholars that has set out to study if the very act of voting is self-reinforcing (e.g. Plutzer 2002; Gerber, Green, and Shachar 2003; Dinas 2012). As discussed in the previous section, there are various possible mechanisms 
governing why voting in one election, all else being equal, increases the probability of voting in a subsequent election. Before investigating underlying mechanisms, the first question to answer is whether habitual voting in this sense exits. While a number of studies have found support for voting being a habit, other studies have failed to do so.

Many studies have used GOTV field experiments to look at whether contacted individuals vote to a greater extent not only in the upcoming election, but also in subsequent elections. Gerber, Green, and Shachar (2003) examined mobilising contacts targeting a random set of registered voters in the 1998 midterm election in New Haven, Connecticut. They found that turnout was higher among the randomly contacted individuals, both at the election at that time and at the subsequent 1999 local election. Other studies of GOTV efforts have also found evidence that they increase long-term turnout (e.g. Cutts, Fieldhouse, and John 2009; Coppock and Green 2016), although questions have been raised about how generalisable those results are. Similar mobilising campaigns in Europe have failed to produce the same effects (Bhatti et al. 2016). Furthermore, there are reasons to suspect that a subpopulation that is susceptible to GOTV targeting is different from the general population (Meredith 2009).

Another way to study habit formation is to take advantage of voting-age restrictions; young people who come of age either just before or just after election day are likely to be very similar, apart from only the former being eligible to vote. This discontinuity is used by Meredith (2009), who shows that Californians who were just over 18 at the 2000 US presidential election were more likely to vote four years later than those who were just under 18 and therefore not eligible to vote in 2000. According to Meredith, the effect of past eligibility on subsequent turnout should be thought of as capturing not only the effect of past participation but also whether information that helped the individual cast that initial ballot continues to have an impact. Dinas (2012) applied a similar strategy to a US panel dataset and found that voting had a positive effect on turnout in subsequent elections. It should, nevertheless, be noted that the sample he uses is small and the estimated effects on turnout in the following elections are imprecise and, in many cases, insignificant. Furthermore, the question of generalisability is relevant here too; Bhatti, Hansen, and Wass (2016) studied Danish and Finnish data and found that past eligibility had either a negative or no effect on turnout.

Bechtel, Hangartner, and Schmid (2018) used a different strategy to estimate voting habits. They compare turnout in the Swiss canton of Vaud-which had compulsory voting in federal referendums between 1925 and 1948-to a synthetic control, i.e. a statistically constructed counterfactual canton made up from turnout in other cantons that did not have compulsory voting. They found that compulsory voting increased turnout by 30 percentage points. This is about twice what is found on average in other studies (Blais 2006). Nevertheless, after compulsory voting was abolished in 1948, turnout decreased to previous levels. Not even in districts with a higher share of young voters, where one might expect a greater impact, were any long-term effects found. In other words, they found no evidence of habit formation. Gäbler, Potrafke, and Rösel (2017) reached the same conclusion in a study where they used the fact that some Austrian states had temporarily introduced compulsory voting in national elections. They used a difference-in-differences approach, where they compared border municipalities across 
two states that differed as to whether or not they had introduced compulsory voting legislation. Their results show that voter turnout increased by 3 percentage points when compulsory voting was implemented but that that effect vanished when compulsory voting was later abolished. In other words, no evidence of habit formation was found.

Most studies of voting habits have examined whether a positive boost in turnout in one election persists over subsequent elections. There are only a few studies focusing on factors that demobilise potential voters and could thereby lead to a habit of abstention. One of these is a study by Franklin (2004, pp. 213-214), in which he claims that the lowering of the voting age to 18 in many democracies in the 1960 and 1970 caused a decline in voter turnout. His argument is based on the assumption that the lower voting age led to more young people encountering their first election before becoming established in an occupation and before forming social networks that could give elections more relevance, and they were therefore more likely to form a habit of abstention (Franklin 2004, pp. 61-62). His empirical analyses are based on aggregated data from several countries at both national and cohort level, as well as individual level data relating to German elections (Franklin 2004, pp. 59-88, 119-169). The results indicate that the section of the electorate whose first elections came after the voting age had been lowered was less likely to cast a vote. The estimated effect on the general turnout is 3 percentage points and this would grow to 4 percentage points when all cohorts who came of age before the voting age was lowered had left the electorate (Franklin 2004, p. 211). Nevertheless, the analyses are studies of correlations; it is possible that the variable referring to early initiation is capturing some other factor not included in the models. The share of the electorate with early initiation increases over time, but many other aspects of society that could affect turnout also change over time. Furthermore, whether or not a person came of age before or after the voting age was lowered is also directly related to age and specific cohorts. Even if age and other control variables are included in the estimated models, the results might therefore be tainted through omitted variable bias.

In another study, Franklin and Hobolt (2011) found that survey respondents in 27 European countries whose first election after coming of age was an EP election voted to a lesser extent in subsequent elections. They claim that the low participation rates in EP elections have thereby had a negative effect on turnout, not only in EP elections but also in national elections in the EU member states. It should be noted, though, that their results might have been affected by other factors, since member states did not randomly join the EU. Furthermore, their claim about the effects of EP elections on national elections is based on regression models where the share of the electorate for whom an EP election was one of their first three elections is the key variable. They identified a significant negative effect of 4 percentage points. In other words, that is the estimated decrease in turnout in national elections when enough time has passed so that the whole electorate has experienced an EP election as one of their first three elections. However, their analysis relies on aggregated data, with potential problems in terms of both omitted variables bias and ecological fallacy. The share of the electorate that has experienced an EP election as one of their first three elections is monotonically increasing over time. It is therefore possible that this variable captures other changes over time. Even though they include a number of control variables to their model, the 
risk of omitted variable bias is still there. Furthermore, other studies have reached the conclusion that habits are formed within specific electoral contexts (Meredith 2009; Coppock and Green 2016; Bhatti et al. 2016). This suggests that experiencing an EP election with a low turnout as the first election after coming of age might not affect the propensity to vote in subsequent elections of other types, including national elections.

In summation, various studies using different techniques have reached contradictory conclusions when it comes to the causal effect of voting in one election on turnout in subsequent elections. Since it is still disputed whether voting is an act of habit, it is perhaps not surprising that few studies have tried to disentangle the mechanisms that might explain how voting habits are formed. The only mechanism that has been tested more carefully is whether voting increases subsequent contacts from political campaigns. Those studies show that voters do not attract more personal contact (Dinas 2012; Green, McGrath, and Aronow 2013), but somewhat more impersonal contact (standard mailings), at least in the US (Rogers et al. 2017). In order for this mechanism to come into play, voting records have to be easily accessible to political campaigners. In the US, commercial vendors provide access to voter files with information not only on previous turnout but also on party affiliation (Igielnik et al. 2018). In many other countries, this is not the case and this mechanism is even less likely to affect turnout.

\section{Turnout and its consequences}

In a democracy, the individual is only a small part of a very large whole. Hence, as stated by Verba and Nie (1972), the social choices made cannot be expected to match the detailed preferences of more than a few citizens. Therefore, responsiveness is not an either-or, nor can it be measured on a simple scale. In the view of Verba and Nie (1972), we should instead consider the question of whose preferences leaders respond to and the mechanisms by which they become aware of those preferences and motivated to act upon them. In this regard, voting is a key mechanism by which citizens both select political leaders and inform them of their preferences. A central question is, therefore, whether the voters are representative of all citizens.

There is an abundance of evidence to suggest that voters are not representative of the electorate in terms of socio-economic status; they tend to have higher incomes, greater wealth and better education than non-voters (e.g. Verba and Nie 1972; Wolfinger and Rosenstone 1980; Verba, Schlozman, and Brady 1995; Leighley and Nagler 2014; Öhrvall 2015). In that sense, the voice of the people is biased towards the socially affluent. Nonetheless, this bias does not necessarily entail that the voters are unrepresentative in terms of policy preferences, nor is this bias necessarily translated into policy outcomes. The effect of the biased turnout is an empirical question, and it has been tackled in previous research.

Wolfinger and Rosenstone (1980, p. 109) reached the somewhat surprising conclusion that, on a set of contested political issues, voters are virtually a carbon copy of the citizen population. Hence, they concluded that the voice of the people is not distorted by participation. It should be underlined that their conclusion only holds as long as the attitudes to social issues are as weakly related to social class as they find in the elections 
they study. Furthermore, many other researchers have reached the opposite conclusion. Leighley and Nagler (2014) find that voters are not representative of the general population, mainly in terms of preferences on social issues and in particular in relation to income distribution (see also Verba and Nie 1972). Even if this inequality does not have any effect on election outcome, it may still be of importance since elected leaders tend to listen more carefully to groups that are politically active (Verba and Nie 1972, pp. 334-343).

Some studies have made ingenious use of compulsory voting to examine if the level of turnout has any effect on policy outcome. For example, Fowler (2013) takes advantage of the fact that compulsory voting was introduced in Australian states at different times as an identification strategy when estimating the effects of different levels of voter turnout. He finds that the introduction of compulsory voting not only significantly increased turnout and offset class bias, but it also affected election outcomes and public policies. Other studies on the effects of compulsory voting have reached the same conclusion (e.g. Bechtel, Hangartner, and Schmid 2016; Carey and Horiuchi 2017).

Taken together, previous research demonstrates that participatory inequality can lead to a bias in election outcomes and political policy that is skewed towards the interests of those who participate. If more equal participation was achieved, the voice of the people, as expressed on election day, would be more representative of the whole electorate. One way to achieve more equal participation is to increase the general turnout. That is the implication of the 'law of dispersion' postulated by Tingsten, which states that as turnout increases, participatory equality also increases. Tingsten's law is evaluated in one of the essays in this thesis, and the conclusion is that it holds. This attaches more weight to the question of how turnout can be increased, which is the focus of the remaining three essays. In two of them, I investigate whether young people's initial voting experience affects turnout in subsequent elections through habit formation. The final essay focuses on student mock elections. These can be seen as a way of giving young people a first voting experience in a suitable context, even if it is not a real election with an impact on public policy.

\section{The Swedish electoral setting}

The essays included in this thesis all analyse voter turnout using data on Swedish elections. In Sweden, elections to parliament (the Riksdag) are held in September every four years, and on the same day as elections to county and municipal councils. Since Sweden became a member of the European Union in 1995, elections to the EP have also been held every five years.* The voting age has been lowered several times, most recently from 20 to 19 in 1969 and then from 19 to 18 in 1975, but since then it has remained set at 18. This means that young people encounter their first national election when they are between 18 and 22 years of age.

*The first Swedish EP election was held in 1995 alongside elections in the nine other states that joined the EU in the same year. From 1999 onwards, EP elections have taken place every five years. 
In many respects, Sweden's institutional arrangements promote turnout. The electoral system is proportional representation, which some studies have found to generate a higher turnout than majoritarian systems, although others have failed to observe the same difference (Blais and Dobrzynska 1998; Blais and Aarts 2006; Stockemer 2017). The cost of voting is relatively small: electoral rolls are produced based on a national population register, which is updated daily. Hence, no one has to register to voteregistration happens automatically. Previous research has shown that registration laws increase the cost of voting and thereby decrease turnout (Rosenstone and Wolfinger 1978; Powell 1986; Highton 1997). Furthermore, Swedish election administration makes it convenient to vote. Sweden also has a generous system for early voting: early voting starts almost three weeks before election day, and votes can be cast in numerous public places, e.g. public libraries and town halls, an arrangement that has been found to facilitate turnout (Fullmer 2015).

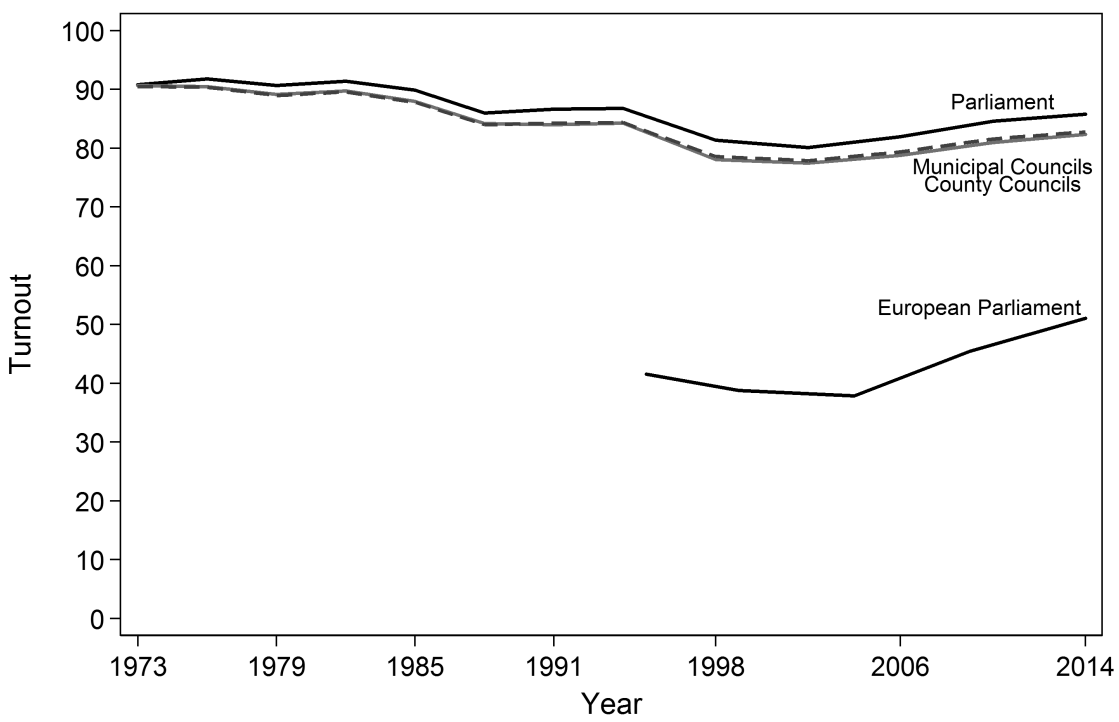

Figure 1: Turnout in Sweden, 1973-2014

Source: Statistics Sweden

As can be seen in Figure 1, voter turnout in Sweden is high. Although it is currently lower than in the 1970s, it has increased over the last few elections. In the most recent national parliamentary election in 2014, 85.8 per cent of the electorate voted. Elections to county councils and municipal councils were held on the same day, and the turnout in those elections was only around 3 percentage points lower. Holding local elections on the same day as the national elections has helped to increase voter turnout in the former. In the 1970s, turnout in local elections was only marginally lower than in national elections, but the gap has widened a little over the decades so that in the 2014 
elections it was more than 4 points. The increasing difference is mainly due to a low, and decreasing, turnout among foreign citizens (Öhrvall 2015). Since 1976, foreign citizens have been entitled to vote in elections to municipal and county councils if they have been registered as resident in Sweden for a continuous period of three years before the date of the election. $\dagger$ Among Swedish citizens the difference in turnout in different elections is minuscule. This is because most people who decide to vote do so in all the elections they are entitled to vote in. Of those Swedish citizens who voted in the 2010 election to the Riksdag, more than 98 per cent also voted in the municipal elections (Öhrvall 2012).

Since Sweden became a member of the European Union in 1995, it has held elections to the European Parliament. When the first Swedish EP election took place in 1995, only 41.6 per cent of the electorate went to the polls, and in the following two elections that share decreased even further. Since then, the trend has reversed, and in the last two elections turnout has increased. In the 2014 EP election, it reached 51.1 per cent, becoming the first time that more than half the electorate turned out for a Swedish EP election.

In comparison with other democracies, turnout in Swedish parliamentary elections has been relatively high over recent decades (Holmberg and Oscarsson 2004; Blais 2007; Solijonov 2016). This is underlined by Figure 2, which shows turnout in EU member states in the 2014 EP election and the national parliamentary election immediately prior to that. Only four EU countries had a higher turnout in national parliamentary elections than Sweden, and in two of those-Belgium and Luxembourg-voting is compulsory. However, as can also be seen in the figure, Swedish turnout in the 2014 EP election was very far below the level reached in the countries with the highest voting rates. In fact, among EU countries, Sweden has one of the biggest differences in turnout between national parliamentary elections and EP elections.

At the individual level, it can be noted that, even though Sweden can be seen as a high-turnout context, previous research has shown that relationships between individual characteristics and the propensity to vote are in line with what has been found in studies based on data from other countries (Öhrvall 2015). The correlation between turnout on the one hand and socio-economic and social factors on the other is strong in Sweden too; voting rates are substantially lower among single individuals and among those with lower education levels and lower incomes. Conversely, voting is more frequent among married couples and cohabitees and those who are well-educated and have higher incomes. Furthermore, as in other countries, turnout is relatively low among the young and the very old.

Altogether, Sweden provides an interesting case for studies of voter turnout. It is a country that differs in some aspects from the US, where most research on voter turnout has been carried out. Nevertheless, research on relationships between individual characteristics and voting produces similar results in both countries, which suggests that the findings might be generalised. Furthermore, turnout in most elections in Sweden

†Since 1995, citizens of EU member states, Iceland or Norway have only had to be registered in Sweden to be allowed to vote. 


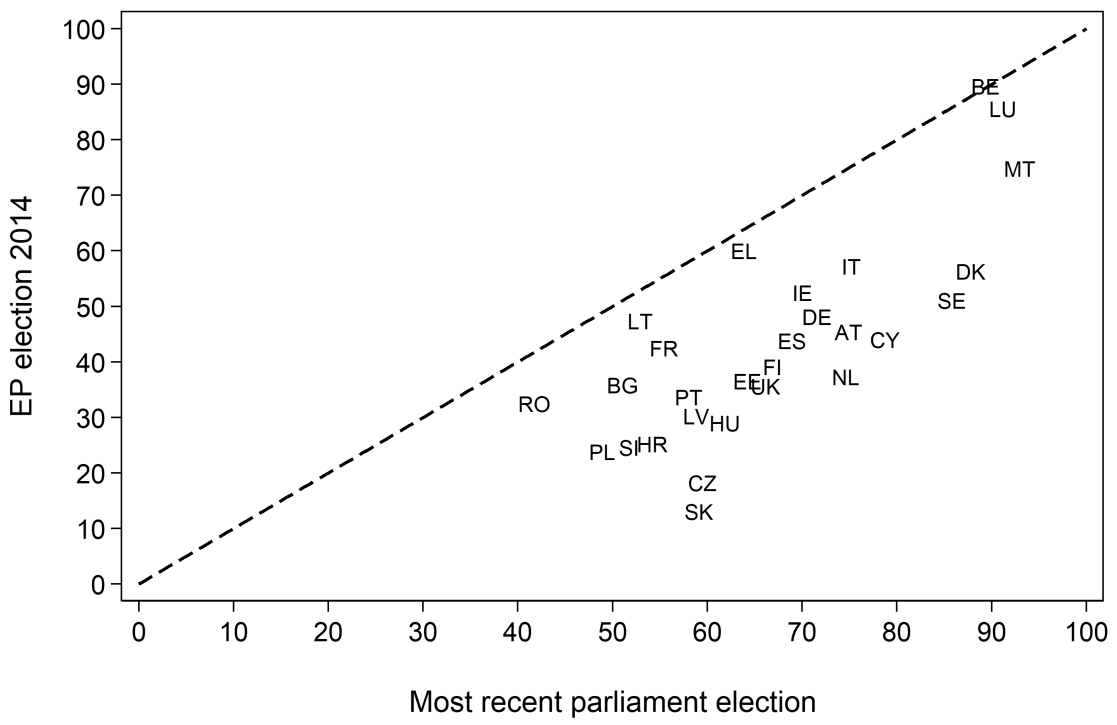

Figure 2: Turnout in EU countries in the 2014 EP election and the parliamentary election immediately prior to that

Source: European Parliament, IDEA and Statistics Sweden Key: $A T=$ Austria, $B E=B e$ lgium, $B G=$ Bulgaria, $C Y=C y p r u s, C Z=C z e c h$ Republic, $D E=$ Germany, $D K=$ Denmark, $E E=$ Estonia, $E L=$ Greece, $E S=S p a i n, F I=$ Finland, $F R=$ France, $H R=$ Croatia, $H U=$ Hungary, IE=Ireland, IT=Italy, LT =Lithuania, $L U=L$ uxembourg, $L V=L a t v i a, M T=$ Malta, $N L=$ Netherlands, $P L=$ Poland, $P T=$ Portugal, $R O=$ Romania, $S E=$ Sweden, $S I=$ Slovenia, $S K=$ Slovakia, UK= United Kingdom

is high, but the turnout in EP elections is much lower than in other elections. As I will return to later, this discrepancy provides interesting research opportunities, and it is used in one the essays in this thesis. Finally, as is described in the next section, Swedish data on voter turnout is of high quality and makes it possible to analyse voting without having to deal with problems of nonresponse and bias due to falsely self-reported voting.

\section{Data and methods}

Most of the classical texts on voter turnout base their empirical analyses on survey data. The data usually comes from extensive interviews with a representative sample of the general population. For example, Campbell et al. ([1960] 1980) analyse national election surveys conducted in 1952 and 1956, while Verba and Nie (1972), and Verba, Schlozman, and Brady (1995) base their conclusions on national population surveys. Such surveys usually include a few thousand respondents, giving enough statistical power to identify 
differences between major population groups. However, if finer nuances are to be discovered or if relationships between several variables are to be explored, then a general population survey of such size might not suffice. This critique has been put forward by Wolfinger and Rosenstone (1980). They claim that early research on voting has been based on datasets that are too small and therefore unable to identify relevant relationships between explanatory factors.

Nevertheless, since the questionnaires in national election surveys and similar population surveys are often of considerable length, it would be costly to use very big samples. An alternative approach is to use studies with bigger sample sizes but with more limited information. For example, Wolfinger and Rosenstone (1980) use the Current Population Survey (CPS), conducted by the US Bureau of Census. They claim that the data they have analysed is about fifty times bigger than those datasets ordinarily employed at that time (Wolfinger and Rosenstone 1980, p. 6). The drawback of their approach is that the CPS and other surveys of a similar kind give only limited information about the respondents, mainly demographic and socio-economic factors. It is therefore possible that relevant variables are not available for the analyses.

Another problem with the data traditionally used to study voting lies in the fact that they are often cross-sectional. Verba and Nie (1972) stress the limitations of survey techniques, especially when they are time-bound and give only a snapshot of the population at a particular moment in time. Using such data, it is difficult to estimate causal effects, even if some steps in that direction can be taken when some assumptions are made, e.g. about the causal ordering of variables or by structuring the variables according to a funnel of causality (Campbell et al. [1960] 1980). Some studies are better suited to comparisons because they use data from different years (e.g. Leighley and Nagler 2014) or different countries (e.g. Verba, Nie, and Kim 1978; Franklin 2004). However, with cross-sectional data it is more difficult to draw conclusions about causality.

There are other aspects of data quality, related to data collection, that are worth paying attention to. Over recent decades, response rates in general population surveys have decreased substantially in the developed world (de Leeuw and de Heer 2002; Massey et al. 2013; Williams and Brick 2018). This development, and the effect of nonresponse on survey estimates, has received considerable attention in the literature (e.g. Groves and Couper 1998; Groves et al. 2002; Meyer, Mok, and Sullivan 2015). Research has shown that the problem is complex; the bias introduced by nonresponse often varies between different estimates from a single survey (Groves and Peytchev 2008). Since a relationship between voter turnout and response rate has been found at the individual level (Holmberg and Oscarsson 2004), it is likely that nonresponse affects estimates of turnout. This is a potential problem for any analysis based on survey data plagued by nonresponse.

Even if sampled individuals comply and answer the questions posed in a survey, the quality of their responses can vary. In studies of voter turnout, the issue of whether or not a respondent answers questions about their voting truthfully is critical. Some survey respondents claim to have voted even if they have not (Katosh and Traugott 1981; Granberg and Holmberg 1991; Bernstein, Chadha, and Montjoy 2001). Since the likelihood of falsely self-reporting voting is not uniform among respondents, this could 
affect estimates and relationships between different variables, and thereby also conclusions on voter turnout (Bernstein, Chadha, and Montjoy 2001). This problem can be avoided by using data with validated information on voting, retrieved through examination of public voting records. Nonetheless, even when voter files are accessible, matching survey respondents with those files can be problematic. A study by Igielnik et al. (2018) of voter files in the U.S. shows that not only are a non-trivial part of the records not matched, but those who do not match are disproportionately in segments of the public who are politically disengaged, belong to minorities, younger, and more mobile. This could in turn lead to biased results.

All the essays included in this thesis use Swedish register data as the basis for analysis. The data also includes validated voting, retrieved from the electoral rolls, thereby avoiding the problem of the over-reporting of turnout among respondents. Since all Swedes have a unique personal identification number that is used in all administrative data, all records from the electoral rolls can be matched to other data. Swedish data also has other advantages compared to data used in many other studies. In Sweden, voter registration is based on the population register and all eligible individuals are automatically registered to vote. In many other countries, such as the US, individuals entitled to vote have to take certain steps in order to become registered to vote. This can entail different selection mechanisms that could, in turn, affect analyses if the electoral rolls are used as sample frames. Furthermore, since the variables used in the analyses presented here are retrieved from register data and not from sample surveys, there is no nonresponse and thus no nonresponse bias. Finally, the Swedish population register is centralised and updated daily. It therefore keeps track of all individuals even if they move to another part of the country or abroad. This means that panel data based on Swedish registers does not have the problem with attrition that many other sample surveys have.

In Essay I, the possible link between turnout and participatory equality is analysed. The study takes advantage of the fact that the 2010 Swedish election to Västra Götaland County Council was ruled invalid, and a re-run election had to be held in 2011 . This meant that the same electorate voted in two elections to the same local government body within a limited time period but in two different contexts: one that stimulated a high turnout and one that did not. The analyses are based on Statistics Sweden's Electoral Participation Survey, a register-based survey consisting of 18,00o individuals who were eligible to vote in the election to the Västra Götaland County Council in 2010 and 2011. The same individuals feature on both occasions, thereby forming a panel dataset. In order to study the relationship between political interest and turnout, two surveys conducted by the Society Opinion and Media (SOM) Institute at the University of Gothenburg were also used: the West SOM survey of 2010 is a postal survey sent out to a simple random sample of 5,503 adults in Västra Götaland County with a response rate of 59 per cent (Elmquist and Bergström 2012), and the re-run election SOM survey of 2011 was sent out to 2,764 adults and had a response rate of 61 per cent (Vernersdotter and Kareliusson 2012).

Essay II focuses on young people encountering their first election. The analyses are based on a sample of 5,000 young people who were entitled to vote for the first time in 
the 2010 election to the Swedish parliament. Some of them were also eligible to vote in the 2009 EP election. The dataset contains information on turnout in the 2010 and 2014 parliamentary elections and the 2009 and 2014 EP elections, and it could thus be seen as a panel study. That sample is also used in Essay III, where the question addressed is whether young people who encounter a second-order election with a low turnout as their first election are less likely to vote in a subsequent election. In that essay, I also use another sample that consists of 1,000 individuals who turned 18, and thereby became entitled to vote, during the two weeks leading up to the Swedish EP election on 25 May 2014, and 1,000 individuals who turned 18 in the two weeks afterwards. This sample has been designed in order to facilitate analysis using a regression discontinuity design, which I return to later in this section.

Some upper secondary schools arrange mock elections at the time of national elections. This gives students information about politics and elections and an opportunity to practise voting, even if they are not entitled to vote at that time. Whether or not these activities have any impact on turnout in real elections is the subject of Essay IV. The study uses unique population-wide administrative data. A recent initiative has seen the complete electoral roll for the Swedish 2009 EP and 2010 general elections scanned and digitised (Lindgren, Oskarsson, and Persson 2017, pp. 46-49). Validated information about turnout is thereby available not only in respect of young people, but also in respect of their parents. The data makes it possible to study the short- and long-term effects of having participated in a student mock election while at upper secondary school.

Apart from the two SOM surveys, all data used in the essays are based on register data. One drawback of using register data is that it does not give as detailed information as a survey, for example information regarding an individual's perceptions and motivations. Nevertheless, since the Swedish national statistical system is to a large extent based on register statistics, a fairly rich set of data can be retrieved from different Swedish registers, e.g. information on age, gender, residence, country of birth, education and income. Individuals can also be linked to their parents and their children through these registers. As mentioned above, the great advantage of the register data used lies in its very high quality, with validated information on turnout and no nonresponse. This ensures more reliable results than can be obtained from studies of voting based on self-reported turnout and afflicted by low response rates.

\section{Methods}

A review of research on turnout conducted during the last century illustrates how statistical methods have developed. Early studies are mainly based on descriptive statistics (e.g. Tingsten 1937; Campbell et al. [1960] 1980). Later research tends to use regression models, such as ordinary least squares (OLS), probit and logistic regressions (Wolfinger and Rosenstone 1980; Verba, Schlozman, and Brady 1995; Lewis-Beck et al. 2008). In recent decades, there has been a substantial critique of what has been termed the naïve use of regression models that came about within quantitative social research as computing power increased (e.g. Morgan and Winship 2014). Today, there is greater understanding of how regression models and other statistical techniques can be used in 
order to reveal causal links, and there is also a much stronger emphasis on explanatory mechanisms (Hedström 2005; Morgan and Winship 2014).

In order to reveal causal relationships between turnout and other variables, the ideal setting is often an experiment in which individuals are randomly assigned to a treatment group or a control group. This design is, however, often difficult to exploit in social sciences. There are experiments carried out in controlled settings, but they often use a specific group of participants (often university students) and hypothetical scenarios. It is therefore possible that the experiment setting is so far removed from reality that its external validity is questionable.

Field experiments may, therefore, sometimes be a more suitable design (Morgan and Winship 2014). For example, electoral districts can be randomly assigned to receive some kind of treatment, such as being targeted with direct mail to encourage them to vote. The level of turnout in those district can then be compared with the level in districts that were not targeted and any difference attributed to the mail campaign. A design of this type was used by Gosnell as far back as 1927 in one of the first thorough studies of voter turnout ever conducted, albeit without the random assignment (Gosnell 1927). This flaw is understandable since adequate statistical techniques were not available at that time, but in 1935 Fisher presented a solid statistical foundation for field experiments within the social sciences (Fisher 1935). This could have been the starting point of extensive research on voter turnout based on field experiments, but research took another route, relying more on general population surveys. It is only in recent decades that there has been a revival in the use of field experiments to explain turnout, most notably through the influential work of Gerber and Green (2000).

The assignment into different groups does not have to be done by the researcher. There are social and political processes that provide situations with random or as-if random assignment. This includes, for example, studies where some individuals are randomly assigned to a programme or service by a lottery (e.g. Angrist et al. 2002), but also less obvious cases. There are also statistical techniques that can be used to find causal mechanisms even if the study does not have the characteristics of an experiment, such as instrumental variable (IV) regressions and regression discontinuity (RD) regressions (e.g. Angrist and Pischke 2009; Rosenbaum 2010).

Essay III is based on a study with an RD design. It compares young people who turned 18, and thus became entitled to vote, immediately before or after a Swedish EP election. Using the vocabulary of experimental research, the treatment group can be seen as those encountering an EP election as the first election after reaching voting age, and the individuals who turned 18 just after election day can be seen as the control group. Since the difference in age between the treatment and control groups is so small, assignment to the two groups can be considered to be as-if random. The causal effect of having a low-turnout election as one's first election experience on propensity to vote in a following election is estimated by comparing the mean turnout of the two groups in a subsequent parliament election.

The other essays included in the thesis mainly use different forms of regression analyses. In Essays I and II, the data materials have a panel design, enabling turnout and estimates of coefficients to be compared for the same individuals on different oc- 
casions. Essay IV is based on a very rich data material, including information about voter turnout not only in respect of the young people studied but also in respect of their parents. When using regression models of this kind, there is always a risk of omitted variable bias (Angrist and Pischke 2009). However, since we are able to use data of such high quality, we argue that this risk is relatively small.

\section{Results}

This thesis contains four essays on voter turnout. In this section, I summarise the findings of those essays. The first essay examines the relationship between voting rates and participatory equality and finds support for such a link. This puts more emphasis on the question of how voter turnout can be increased. As discussed in previous sections, some scholars argue that voting should be seen as a habit that is formed early. This implies that electoral reform and campaigns aiming to increase voting rates, and thereby participatory equality, should focus on stimulating voting among young people, since this could have both short- and long-term impact. However, the question of whether or not voting is habitual is a debated one. The other three essays in this thesis aim to bring evidence to this debate by using different approaches to address the issues of turnout among young people encountering their first election and how voting habits are formed.

Depending on their birthdate and when elections take place, young people have their initial election experience at different ages and therefore in diverse social contexts. I study the impact of those differences on turnout in both the first and second election they experience in Essay II. The main purpose of the study is to examine if an advantageous context can promote turnout in a way that endures through habit formation. Date of birth also determines what type of election a young person first encounters. In Essay III, I analyse whether an initial experience of a low-stimulus election leads to a lower turnout in a subsequent election. One way to ensure that young people have a positive first electoral experience is for schools to arrange student mock elections. These are elections that in many respects resemble real elections, and if combined with social science education they might foster a habit of voting that then applies to real elections. Whether that is true is the topic of the fourth and final essay.

Since three of the essays in various ways address turnout among young people and the formation of voting habits, I conclude this section by discussing how their combined results should be interpreted. The implications of the findings of this thesis are presented in the following and final section of this introduction.

\section{Essay I}

If some groups in society vote to a lesser extent than others, the public voice expressed at the voting booth becomes biased. This might affect election outcomes and determine who gets into public office. It might also influence policy outcomes and how responsive policymakers are to concerns raised by different communities. Even if voting is less unequal than other forms of political participation, it is still biased in favour of 
more socially affluent citizens (Lijphart 1997). Previous studies have found that these participatory inequalities have effects on political priorities and policy outcomes (e.g. Verba and Nie 1972; Fowler 2013; Bechtel, Hangartner, and Schmid 2016). One remedy suggested by Lijphart (1997) is to implement reforms to increase voting rates. His proposal is based on the assumption that a higher turnout entails a more equal turnout, as suggested in previous research by Tingsten (1937).

Essay I, co-written with Mikael Persson and Maria Solevid, addresses this relationship between the level of turnout and participatory equality (Persson, Solevid, and Öhrvall 2013). In the article, we revisit the 'law of dispersion', which was formulated by Tingsten (1937, p. 230) in his seminal book Political Behavior as follows:

All the facts gathered here indicate the existence of a rule which may be termed the law of dispersion; according to this rule the dispersion (the differences) in regard to participation in an election or within a certain group, is smaller the higher the general participation is.

In other words, Tingsten argues that turnout biases get worse as turnout decreases. It is worth noting, as acknowledged by Tingsten (1937, p. 230), that if the general turnout is very high, no group of a substantial size could have a very low turnout. This is just simple arithmetic. For example, if the general turnout in a country with equal numbers of men and women is 90 per cent, then the minimum turnout for one of the sexes is 80 per cent (which occurs if turnout is 100 per cent for the other). A lower turnout thereby gives room for more dispersion. However, this does not necessarily mean that, as the law states, participatory inequality becomes greater when voter turnout decreases.

Tingsten (1937) based his argument on an analysis of official statistics on voting rates by sex, age, occupation and social status in a number of different countries. In that analysis, he compared differences in turnout in percentage points. As argued by Sinnott and Achen (2008), however, in order to measure bias in turnout we ought to study relative change in per cent rather than absolute change in percentage points. $¥$ As a hypothetical example, suppose that in a country there are only two equal-sized groups in terms of educational attainment, and in one election the voting rate for those with a high level of education is 75 per cent, while for those with a low level of education it is only 40 per cent. In the next election turnout for the two groups drops by 15 and 10 points respectively. In other words, the drop in percentage points is bigger for those who are highly educated. Nonetheless, the bias has increased: in the first election those who were poorly educated constituted 35 per cent of voters, and in the second their share of the vote had dropped to 33 per cent. The voters thereby became less representative of the population, where the groups each constituted 50 per cent. This is because the relative change in relation to the initial level of turnout was bigger among those with a low level of education $(10 / 40=25 \%)$ than among those with a high level of education $(15 / 75=20 \%)$.

\$According to recalculations carried out by Sinnott and Achen (2008), Tingsten did still draw the correct conclusion from his data. 
Tingsten's law has been influential on the literature on turnout (e.g. Lijphart 1997; Hajnal and Trounstine 2005; Finseraas and Vernby 2014), but although it was first presented more than eighty years ago, there have been few empirical tests of it. Rosenstone and Hansen (1993, pp. 241-243) compare different US presidential elections and find that when more people turn out to vote, they are more representative of the electorate. This result is, however, mainly driven by two unusual elections (see Sinnott and Achen 2008). Sinnott and Achen (2008) only find scattered support for the hypothesis that class biases get worse as turnout drops. In their study, they examine levels of turnout by income, education and class, and find no support for Tingsten's law in the US and only scant support for it in Europe. They claim that the law applies rather to political engagement, and that engagement is the causal variable to focus on when explaining turnout. Even if they are correct in their claim, this begs the question: what then explains political engagement? Furthermore, this argument does not recognise that even if engagement can explain social bias in turnout, the bias might nevertheless have an impact on public policy in a way that is advantageous to those who turn out to vote.

In Essay I, we contribute to this debate by exploiting a rare and fortunate electoral event. The Swedish 2010 election to the Västra Götaland County Council was ruled invalid and a re-run election took place in 2011. The same electorate thus voted in two elections to the same local government body within the space of less than eight months. Furthermore, compared to previous studies, our data has some advantages, as discussed in the previous section. These include validated voting, no nonresponse and high-quality register data on individual characteristics such as income and educational attainment.

We empirically test Tingsten's law by comparing regression models estimated for the two elections and with voter turnout as the dependent variable. Our analysis of the first election in 2010 reveals differences in voting rates according to socio-demographic characteristics that are in line with previous research (e.g. Wolfinger and Rosenstone 1980; Franklin 2004). In the re-run election, voter turnout declined by almost half, from 80.6 per cent to 44.1 per cent. The relatively modest differences relating to age, income, education, and political interest in the 2010 regular election were much greater in the 2011 re-run election. This is true when we compare both absolute and, more importantly, relative differences. Our main conclusion is that the voting rates in the re-run election led to a turnout more biased in favour of those who are socio-economically richer, and this result lends support to Tingsten's law of dispersion. It is also worth noting that when we control for political interest in our models the coefficients for the other covariates barely change. Political interest does not have the dominant role as suggested by Sinnott and Achen (2008).

One caveat is in place: it should be noted that the result in Essay I is based on a comparison of a fairly low level of turnout with a higher one. It is possible that a different conclusion would be reached if participatory equality was evaluated when comparing a very low level of turnout with a somewhat higher, but still fairly low, level of turnout. I am referring to turnout levels of around 20 per cent, as in some countries in EP elections. Hopefully, future research will expand upon our study and cover such cases too. Nevertheless, the levels of turnout compared in Essay I are similar to those found in 
many countries and the results should therefore be broadly relevant. A later study by Bhatti et al. (2018) also confirms our findings.

\section{Essay II}

Previous research on habitual voting gives a divided picture. Some studies have found that the act of voting is self-reinforcing and that voting should be seen as a habit that can be acquired (e.g. Green, Gerber, and Nickerson 2003; Dinas 2012), while others have failed to observe the same results (e.g. Bechtel, Hangartner, and Schmid 2018; Gäbler, Potrafke, and Rösel 2017). If the decision on whether to turn out to vote is affected by previous turnout, the first election a young person encounters is likely to be of particular importance, because at that time they have no previous voting record. Many scholars have also emphasised the importance of the first election after coming of age (e.g. Plutzer 2002; Smets 2016; Bechtel, Hangartner, and Schmid 2018).

Elections usually take place some years apart, and young people will therefore face their first election at different ages. Since they are in a disruptive part of the life-cycle, those young people will be more or less likely to be in a social context that promotes turnout depending on their age. In Essay II, I take advantage of this difference in contexts when I examine turnout among young people who face their first election at different ages and how this affect their propensity to vote in their first and second election.

The study is based on Swedish panel data with validated voting records for a sample of 5,00o young people who were entitled to vote for the first time in a Swedish national parliamentary election in 2010. Some of them were also eligible to vote in the $2009 \mathrm{EP}$ election. $\$$ The dataset contains information on validated turnout in the 2010 and 2014 parliamentary elections and the 2009 and 2014 EP elections, together with high-quality register data on age, sex, immigration background, parents' educational attainment, school enrolment and residence. Since Sweden has a four-year election cycle and a voting age set at 18 , the young people encountered their first national election when they were between 18 and 21. Most Swedish 18-year-olds live at home and are enrolled in upper secondary school, while most of those who are slightly older have left school and have often moved away from their parents.

The results of the analysis shows that turnout in the 2010 national parliamentary election was substantially higher among 18-year-olds than among their slightly older peers. If we compare them with 20 -year-olds, the estimated difference is almost 9 percentage points and statistically significant. That turnout is higher among 18 -year-olds is in line with what has been found in previous studies (Öhrvall 2009; Bhatti and Hansen 2012a; Konzelmann, Wagner, and Rattinger 2012).

Those estimated differences in turnout on the basis of age change only marginally, and are still statistically significant, when I include controls for sex, parents' educational attainment and foreign background in the regression model. This is expected since those control variables are all time-invariant and are not expected to differ in any

\$It might be suspected that this first electoral experience of an EP election would influence turnout in the national parliamentary election, but, as shown in Essay III, this does not seem to be the case. 
substantial way in relation to year of birth. When I add controls for enrollment in upper secondary school and whether the young people are living with any parent to the model, the estimated differences in turnout between age categories decrease substantially and are no longer statistically significant. Together, these results give support for the conclusion that the difference in turnout by age is not due to something related to socio-economic background or demographic composition, but has to do with the social contexts that they are embedded in.

If voting is a habit and the first election is important for forming such a habit, then the relatively high turnout among Swedish 18-year-olds is expected to persist at the next election four years later. But this is not the case: when they have their second opportunity to vote in a national parliamentary election in 2014, the difference in turnout by age is minuscule and far from statistically significant. In other words, there is no sign of habit formation.

Since 18-year-olds are more likely to still be attending school and living with their parents, one might assume that they are also more likely than those a few years older to change address between the two elections. This could have a disruptive effect on voter turnout, not only by affecting social ties but also by increasing the cost of voting, e.g. by having to find out the location of the polling station (Highton 2000; Plutzer 2002). However, the result still holds even when I restrict the analysis to those who were living in the same municipality in both elections.

It is worth mentioning that turnout in Swedish parliamentary elections is high, both in general and among young people encountering their first election (Öhrvall 2012). In order to see if the result holds in elections with a lower turnout, Essay II also includes a corresponding analysis with turnout in Swedish EP elections as the outcome variable. The turnout in Swedish EP elections is almost half of that in national parliamentary elections, but the result of the analysis is the same: in the 2009 Swedish EP election, voting rates were much higher among 18-year-olds than among those who were 19 or 20, but no such difference was found in the following election in 2014. Taken together, the results presented in Essay II indicate that the first election after coming of age is not as important for future turnout, in terms of habit formation, as some previous research has suggested.

\section{Essay III}

Elections to the EP have been classified as second-order elections (Reif and Schmitt 1980; Hix and Marsh 2011). In most member countries, turnout has been dismal. Franklin and Hobolt (2011) argue that the low levels of turnout in EP elections have also had a negative effect on turnout in national elections. This claim is based on the assumption that voting is a habit formed early in life and that the first elections are of crucial importance. For citizens in EU member states, one of the first elections after coming of age will be an EP election, i.e. a second-order election with low turnout. Franklin and Hobolt also find support for their claim in their empirical analysis. However, their analysis relies on aggregated data, with potential problems in terms of both omitted variables bias and ecological fallacy. 
In Essay III, I use what I argue is a more adequate design and better data to examine if having a low-turnout election as the first election after coming of age has an effect on turnout in a subsequent national election. The analysis is based on the 2014 Swedish EP and national parliamentary elections. The Swedish case is of particular interest since Sweden has one of the biggest differentials in turnout between EP elections and national elections; in the 2014 elections that differential was 35 percentage points. If having a low-turnout election as the first election experience affects the likelihood of voting in a following election, then Sweden provides a setting where this effect is likely to be found.

The study is conducted using an RD design, which facilitates estimation of causal effects. I take advantage of the strict voting-age restrictions in elections which mean that young people who come of age just before or after election day are likely to be very similar, apart from only the former being eligible to vote. The main sample consists of two groups: 1) young people who turned 18, and thus became entitled to vote, in the two weeks before the Swedish EP election in May 2014; and 2) young people who turned 18 in the two weeks following the election and were therefore not entitled to vote in the EP election but could vote in the national parliamentary election later the same year. The two groups can be seen as a treatment group and a control group, where the treatment consists of being entitled to vote in the EP election. The causal effect is estimated by comparing the mean turnout in the two groups in the following parliamentary election in September 2014. Since 2014 can be seen as a special occasion with the two elections very close in time, I use a similar RD design to also study the effect that having the 2009 EP election as one's first election experience has on turnout in the 2010 parliamentary election. The data includes validated voting records, and, because all covariates are retrieved from registers, there is no nonresponse.

The results show no negative effect of having an EP election as the first electoral experience. Quite the contrary: my examination of the 2014 elections reveals a positive effect on turnout in the parliamentary election. This might be due to the short interval between the two elections and an overlap between the two political campaigns. Young people who were entitled to vote in both elections might therefore have been exposed to more political information than those who turned 18 after the EP election. However, the effect vanishes when I control for age in days. It can be debated whether a control for age should be added when the difference is less than a month, but it nevertheless casts some doubt on whether there really is a positive effect.

In any case, I do not find any support for the claim that having an EP as the first election experience has a negative effect on turnout in a following national election. This result also holds when I examine whether having the 2009 EP election as the first election after coming of age had any effect on turnout in the 2010 parliamentary election. My study therefore contradicts the results of Franklin and Hobolt (2011). The difference might be due to our different research designs, and I argue that the design I use is more suitable than theirs. 


\section{Essay IV}

Over the years, much effort has been devoted to increasing political interest and participation among young Swedes. One example of such efforts is student mock elections, in which students both receive information about the political process and get to practise casting a vote. Mock elections have been held at a number of Swedish lower and upper secondary schools during election years since at least the end of the 196os. From 1998 onwards, this developed into a broader initiative with national campaigns and a public presentation of the total vote tally. This brought mock elections to more people's attention and the number of participating schools has subsequently increased. The mock elections are funded by the government and can be seen as part of their efforts to increase political interest and efficacy among young people in Sweden.

Student mock elections are not peculiar to Sweden; they take place in many countries across the world (Borge 2016). In some countries they are organised nationally, and in others, such as the US, initiatives may be regional or even come from a single school. The country with the longest history of student mock elections is Norway, where students have participated in such elections since after the Second World War. They have also received scholarly attention. Borge (2017) finds that students who vote in Norwegian mock elections are also more likely to express an intention to vote in subsequent real elections. This correlation cannot be interpreted causally since it could be due to various factors not controlled for. Furthermore, it is very possible that this intention to vote does not translate into actual voting; after all, talk is cheap.

No previous study has examined the effects of mock elections on turnout in real elections. In Essay IV, co-written with Sven Oskarsson, we attempt to fill this gap. The analysis is based on unique administrative data that provides information on turnout in the Swedish 2009 EP and 2010 general elections for everyone in the population eligible to vote. This data, combined with information on which upper secondary schools arranged mock elections between 1998 and 2010, makes it possible to estimate the effects on turnout of having been enrolled in a upper secondary school that ran a mock election.

When we use a regression model to study all upper secondary school students between 1998 and 2010, we find that those who were enrolled in a school that arranged a mock election voted to a slightly greater extent in the 2010 Swedish parliamentary election than those students who were enrolled in a school that had no mock election. The schools that arranged mock elections are not, however, a random sample of all Swedish upper secondary schools. A direct comparison of turnout among students who have or have not been exposed to a mock election is likely to be afflicted by bias. We therefore add sets of control variables to our models at both the school and individual level, including student grades and turnout among parents. This leads to a substantial decrease in the estimated effect of having experienced a mock election, and it becomes minuscule and statistically insignificant.

Although we do not find that having been enrolled in a school that arranged a mock election has any general effect on turnout, it is possible that such an effect might be found in specific subgroups. In previous literature, the school has sometimes been seen 
as an institution that can compensate for the different socio-economic backgrounds of its students (e.g. Rosenstone and Hansen 1993, p. 136). If such compensatory effects exist, it is possible that we might find that being exposed to a mock election has an effect on turnout among those who have a poor socio-economic background and are therefore less likely to vote. On the other hand, it is also possible that students with a rich socioeconomic background are more susceptible to the influence of a mock election and the associated political information, and that we are therefore more likely to observe an effect in that group instead. In order to examine whether such heterogeneous effects exist, we have estimated models where we have split our sample into quartiles depending on socio-economic background and run separate regressions for each group. Although we have a large sample and relatively precise estimates, we do not find any significant effects in any of the quartiles. This indicates that mock elections do not have any compensatory effect on political participation, and nor do they increase participatory inequality.

In the essay, we also examine whether mock elections have different effects in the short and long term by separately studying students enrolled in upper secondary school in 1998, 2002, 2006 and 2010. We do not find there to be any clear pattern, and the overall conclusion is that mock elections do not increase turnout in real elections. Finally, we have carried out a corresponding analysis with turnout in the 2009 EP election as the outcome variable. This was done in order to see if we could identify an effect on voting in an election where relatively few people turn out to vote. But the result is the same there too-the estimated effect is insubstantial and insignificant. Taken together, the main conclusion in the essay is that mock elections do not promote voting in real elections. However, as I return to when I discuss the implications of this in the final section, there are other reasons for schools to arrange mock elections apart attempting to influence turnout.

\section{First elections and habit formation}

Three of the essays contained in this thesis have looked in different ways at whether voting is an act of habit, by focusing on turnout among young people encountering their first elections. The theory of habitual voting states that, other things being equal, casting a vote in one election increases the probability of voting in a subsequent election. In this field of research, the initial level of turnout among young people is of particular importance (e.g. Plutzer 2002; Franklin 2004). Those encountering their first election after coming of age could, according to this theory, form a habit of either voting or abstaining. As discussed in the section on theoretical approaches to voter turnout, there are various possible mechanisms that might explain why voting is self-reinforcing, and I have classified those mechanisms into three categories where voting can: 1) decrease the cost of future voting; 2 ) change the individual's psychological orientation towards political matters and voting; and 3) increase the probability of being targeted by various GOTV campaigns in subsequent elections. There have, however, been few attempts to work out which mechanisms are at play. This is not surprising since the question of whether voting is a habit has not yet been settled-previous studies have reached 
contradictory conclusions. The results presented in this thesis are in line with earlier studies that have failed to find empirical support for the theory of habitual voting (e.g. Gäbler, Potrafke, and Rösel 2017; Bechtel, Hangartner, and Schmid 2018).

Essay II shows that 18 -year-olds, who are embedded in an advantageous context, vote to a substantially greater extent than their slightly older peers also encountering their first national parliamentary election after coming of age. By voting they gain knowledge about how to vote, and they obtain at least some political information, which might be expected to lower the cost of future turnout. They might also receive some positive reinforcement from family and friends, which could help to form a selfimage as a politically-involved citizen (Plutzer 2002). Nevertheless, when the same individuals face their second election, the earlier difference in turnout by age disappears. This result also holds when I study EP elections, and also when I restrict the analysis to a subset of young people who have not moved to a new municipality between elections. The design of the study is not experimental, so it is not possible to establish any causal mechanisms, but the results are consistent for different types of elections and they are not what is to be expected if voting is self-reinforcing.

In Essay IV, we reach a similar conclusion when we study the effects of student mock elections on turnout in real elections. Mock elections are not real elections-which determine who gets elected and what public policy will be implemented-and they are not discussed in the literature on habitual voting. However, by providing students with information about political parties and the electoral system, and also enabling them to practise casting a ballot, mock elections could, through the first two of the abovementioned mechanisms, increase the probability of voting in subsequent real elections. But we discover no such effect, neither in the short term nor the long term, regardless of the socio-economic background of the young people we study.

As shown in these two essays, a positive boost in terms of political information and experience of voting does not seem to increase turnout at the next election, even though it might be expected to reduce the cost of voting and possibly promote a positive civic orientation. On the other hand, a negative first electoral experience does not seem to decrease turnout either, as shown in Essay III. At least, I do not find that experiencing an EP election as one's first election after coming of age has a negative effect on the propensity of voting in a subsequent parliamentary election. The design of that study makes it possible to interpret the results causally.

Taken together, Essays II-IV look in varied ways at turnout among young people and the importance of the first election in forming a habit of voting. Although the studies use different data materials, methods and research questions, the main conclusion is the same: the first election after coming of age does not have a substantial impact on future turnout. This result has some profound implications, not least for the debate on lowering the voting age, as I will return to in the next section.

Although for the analyses described here I have used data on turnout in both national parliamentary elections with high voting rates and EP elections with low voting rates, all the data refers to elections in one country-Sweden. The relationships between different individual characteristics and turnout in Sweden have been found to be similar to what is found in other countries (Öhrvall 2015), so there is reason to expect that 
the results are also valid in other electoral contexts. Nevertheless, it is worth reiterating that the cost of voting is relatively low in Sweden; registration is automatic, voting cards with information about the location of the polling station are distributed to all individuals entitled to vote, and there are plenty of opportunities to cast an early vote at different public locations, both before and on election day. In some countries, such as the US, citizens have to register in advance to cast a vote, which may be an arduous process. This represents an additional cost of voting that is removed after the first occasion (unless a change of residence demands re-registration). It is therefore possible that, in such a context, voting in one election reduces the cost of voting in subsequent elections in such a way that voting becomes self-reinforcing. Additional research is therefore warranted in order to become more confident of the generalisability of the results presented here.

\section{Implications of the findings}

Political equality is a fundamental democratic ideal. Verba, Schlozman, and Brady (1995, p. 1) state this in the following way:

In a meaningful democracy, the people's voice must be clear and loudclear so that policymakers understand citizen concerns and loud so that they have an incentive to pay attention to what is said. Since democracy implies not only governmental responsiveness to citizen interest but also equal consideration of the interest of each citizen, democratic participation must also be equal.

In order for the voice of people to be heard clear and loud, some conditions have to be met. Verba (2003) differentiates between three aspects of political equality: equal rights to vote, equal capacity and opportunity to vote, and equal voice. The first includes universal adult suffrage, on the principle of 'one person, one vote', and can be seen as the foundation of democracy. The second refers to the resources necessary to participate. This includes civic skills and the political knowledge required to vote in accordance with one's preferences. In this regard, voting is more equal than other forms of participation, which usually demand more skills and often require more resources, such as time and money. These first two aspects can be seen as preconditions for the thirdequal voice. Nevertheless, even if one has the right and the capacity to vote, one may for various reasons choose not to cast a vote. This lack of voice makes it difficult to achieve the goal of equal consideration of the interest of each citizen.

Even if equal voice is a democratic ideal, one could argue that low turnout might not be a problem if turnout was equally low across all social groups, or across all other groups with distinct political preferences. If that was the case, the voice of the people would still be representative of the electorate and the election results could be considered unbiased. Previous studies have, however, provided plenty of evidence that voting is not an equal form of participation; non-voters are drawn disproportionally from 
among the young, the poor, and the less educated (e.g. Verba and Nie 1972; Wolfinger and Rosenstone 1980; Leighley and Nagler 2014).

If participation is unequal, the voice of the people as expressed at the polls will become biased. This not only affects who gets into office but also creates the risk of politicians paying more attention to the interests of voters than of non-voters. As Rosenstone and Hansen (1993, p. 247) put it, 'the simple fact is that democratic government provides few incentives for leaders to attend to the needs of people who neither affect the achievement of their policy goals nor influence the perpetuation of their tenure in office.' Differences between voters and non-voters thereby become important not only in terms of what they express but also in terms of who they are (see also Verba, Schlozman, and Brady 1995).

More equal participation could, therefore, be a means of bringing about governmental responsiveness that considers the interest of all citizens equally. Even if the distribution of non-voters over groups is more relevant to equal voice than the level of turnout, the two could be linked. This is the idea behind the law of dispersion, as formulated by Tingsten (1937, p. 230), which states that as turnout increases, participatory equality also increases. The results presented in this thesis give support to Tingsten's law.

One implication of these results is that one way to make voters more representative of the electorate is to increase the overall turnout. In other words, it is not necessary to target specific groups with particularly low voting rates; as long as the general turnout increases, we can expect turnout to be more equal and election results a better reflection of the will of the people. Even if this is easier said than done, this finding can assist the design of GOTV campaigns. The results also put more emphasis on electoral reforms that could help improve turnout. This includes reforms of election administration that lower the cost of voting, such as automatic voter registration and accessible polling stations with generous opening hours (see Highton 1997; Highton 2004; Garmann 2017; Lisa, Mason, and Meera 2017). It also includes reforms that increase incentives to vote. For example, studies have shown that turnout in subnational elections benefits from concurrent national elections (Cancela and Geys 2016). Conducting a national referendum at the same as an EP election might also be another way to increase turnout. Another approach is advanced by Lijphart (1997), who advocates compulsory voting, based mainly on the argument that it would increase turnout and participatory equality. Previous research confirms that such a reform would increase turnout, even if the effect depends on the sanctions and how strictly they are enforced (Cancela and Geys 2016; Stockemer 2017). Hence, compulsory voting would be likely to bring about a more equal turnout, but it might be seen as a radical change, as well as morally unjustifiable, to deprive citizens of a free choice as to whether to cast a ballot or not, and there is some evidence that it could increase dissatisfaction with democracy in some population segments (Singh 2018). 


\section{Lowering the voting age}

One reform suggested in the literature to increase turnout is to adjust the voting age. This suggestion has been put forward by Franklin (2004, p. 213). He claims that the lowering of the voting age to 18 in many Western countries that took place in the 1960s and 1970s led to a decline in voter turnout (Franklin 2004, pp. 190-191, 213-214). As described in the previous section on theoretical approaches to voter turnout, this claim is based on the assumption that 18 is a particularly ill-chosen voting age, because it leads to many young people encountering their first election at a disruptive time in life, when they are not embedded in a social context that promotes turnout (Franklin 2004, pp. 63-66). If voting is a habit formed by the first elections a young person encounters, as Franklin believes, abstention in that first election could have detrimental long-term effects on voter turnout. He therefore argues that either a higher or a lower voting age would be preferable to 18 , but since he recognises that the former would not be politically possible, he recommends lowering the voting age further (Franklin 2004, p. 213).

As of today, Austria is the only European country to have lowered the general voting age below 18. It is now set at 16. There are, however, some German and Swiss states where 16-year-olds are entitled to vote in local elections, and steps in the same direction are also being taken in other parts of Europe. In Norway, there have been experiments with lowering the voting age to 16 in some local elections (Bergh 2013). A Swedish commission of inquiry appointed by the government has suggested that similar experiments should also be carried out in Swedish municipal elections before lowering the voting age for all elections (SOU 2016). This development has been supported by various actors. In 2015, a resolution adopted by the European Parliament (2015/2035(INL)) recommended that member states harmonise the voting age at 16 for EP elections.

The results presented in this thesis support Franklin's conjecture that the social context is important and that turnout is relatively low among people aged 20 or 21 , who are more likely to be out of school and in the process of establishing a new life away from the family they grew up in. From previous research there is reason to expect that voting rates among the 16 and 17-year-olds, who would become enfranchised with a lower voting age, would be relatively high. Zeglovits and Aichholzer (2014) have studied turnout in two Austrian regional elections and found that the voting rate in the 16-17 age group was higher than among 18-21-year-olds, who were also eligible to vote for the first time. Bergh (2013) observed a similar result in the Norwegian trial in which the voting age was lowered from 18 to 16 in some municipalities. Although these studies do not present detailed estimates of voting rates at each specific age, it is reasonable to assume that lowering the voting age to 16 would lead to a turnout among 16 and 17-year-olds that is on a par with that of 18 -year-olds.

Lowering the voting age to 16 is, hence, likely to lead to more young people casting a vote in their first election after coming of age. Although such a reform would per definition bring about a more numerous electorate and in all certainty bring more voters to the polls, it would most likely have a limited direct effect on the general turnout since 16 and 17-year-olds would constitute a small share of the electorate and their turnout is expected to be around the average (Bergh 2013; Zeglovits and Aichholzer 2014). Never- 
theless, the argument put forward by Franklin (2004, pp. 21-22, 213-214) is focused on the long-term effect. By voting in their first election, it is expected that young people will be more likely to form a habit of voting and thereby vote to a greater extent than they otherwise would. According to this line of thought, the reform would have a gradual impact on the electorate as more and more generations have an early electoral initiation. However, the results presented in this thesis do not support this theory-the first election does not seem to have any substantial impact on future turnout. One implication of these results is that lowering the voting age is not likely to increase voting rates, not even in the longer term.

It should be noted that there are other arguments for lowering the voting age besides any potential effect on voter turnout. Some scholars claim, on the basis of legal and philosophical arguments, that 16 and 17-year-olds ought to be allowed to vote (e.g. Hart and Atkins 2011). There are also studies that show that 16 and 17-year-olds demonstrate no less ability to participate than that of their slightly older peers (Hart and Atkins 2011; Wagner, Johann, and Kritzinger 2012). At the same time, other studies find them to be less politically mature and therefore caution against a lower voting age (Chan and Clayton 2006; Bergh 2013). This broader debate about the voting age is beyond the scope of this thesis; I merely state that the results presented here suggest that such a reform would not increase turnout.

Even if the voting age is not lowered, young people who have not reached voting age can get election experience through mock elections arranged in schools. Such elections give students a chance to practise voting, albeit in a hypothetical setting without any political consequences. Schools can combine this activity with education on the political system and information about party platforms. Together, this could lower the cost of voting when those adolescents face their first real election a few years later, and thereby increase their propensity to cast a vote. Studies examining Danish mock elections have found that they increase students' political efficacy and improve their political knowledge (Hansen, Hansen, and Levinsen 2015; Hansen 2017). Nevertheless, the results presented in this thesis show that mock elections do not increase turnout in real elections, neither in the short nor the long term. This is not to say that mock elections do not have merit; they can be a valuable part of social science education in schools and provide an opportunity to increase students' interest in political matters, even if they do not have any impact on future turnout.

\section{Mobilising young people}

In this thesis, I have set out to study turnout among young people and habit formation. The main conclusion is that the first election after coming of age does not have a substantial impact on future turnout. This could be seen as a discouraging resultefforts to increase voting rates do not seem to have long-lasting effects as the theory of habitual voting proposes. But the results could also be interpreted in a more positive light: young people whose first election comes during a disruptive phase of life, or whose birthdate means that their first electoral encounter is a second-order election that draws few to the polls, are not doomed to lower turnout in elections that follow. 
Even if there are no voting habits to consider, turnout among young people is a topic worthy of attention. It has been well-established in previous research that their voting rate is relatively low (e.g. Campbell et al. [1960] 1980; Wolfinger and Rosenstone 1980; Bhatti, Hansen, and Wass 2012; Leighley and Nagler 2014; Öhrvall 2015). Studies have found that the decline in turnout in a wide range of democracies over recent decades has been especially pronounced among young people, thereby creating a widening generational gap (e.g. Smets 2012; Blais and Rubenson 2013). For anyone striving to make voters more representative of the whole electorate, the question of how to stimulate turnout amongst the young is vital. The law of dispersion formulated by Tingsten (1937), and supported by the results presented here, states that a higher turnout entails a more equal participation. This means that reforms and efforts to increase general turnout are likely to decrease the gap in turnout by age. However, it is still useful for mobilising campaigns to target young people encountering their first election. Since they lack a voting history, they might have a greater demand for political information, and they might also be easier to persuade to cast a vote. As shown in this thesis, many young people encountering their first election do turn out to vote. The social context seems to be a crucial factor, and perhaps a better understanding of the social logic behind voting is the key to increasing turnout among young people. However, this thesis also shows that we should not expect one-off GOTV campaigns to have effects that last over time. 


\section{Bibliography}

Aldrich, John H., Jacob M. Montgomery, and Wendy Wood (2011). “Turnout as a Habit”. In: Political Behavior 33.4, pp. 535-563.

Angrist, Joshua D., Eric Bettinger, Erik Bloom, Elizabeth King, and Michael Kremer (2002). "Vouchers for Private Schooling in Colombia: Evidence from a Randomized Natural Experiment”. In: American Economic Review 92.5, pp. 1535-1558.

Angrist, Joshua D. and Jörn-Steffen Pischke (2009). Mostly Harmless Econometrics: An Empiricist's Companion. 1 edition. Princeton: Princeton University Press.

Barry, Brian (1978). Sociologists, Economists, and Democracy. Cicago: University of Chicago Press.

Bechtel, Michael M., Dominik Hangartner, and Lukas Schmid (2016). "Does Compulsory Voting Increase Support for Leftist Policy?” In: American Journal of Political Science 60.3, pp. 752-767.

- (2018). "Compulsory Voting, Habit Formation, and Political Participation”. In: The Review of Economics and Statistics 100.3, pp. 467-476.

Berelson, Bernard R., Paul F. Lazarsfeld, and William N. McPhee [196o] (1986). Voting: A Study of Opinion Formation in a Presidential Campaign. Reprint edition. Chicago: University Of Chicago Press.

Bergh, Johannes (2013). "Does Voting Rights Affect the Political Maturity of 16- and 17Year-Olds? Findings from the 2011 Norwegian Voting-Age Trial”. In: Electoral Studies 32.1, pp. 90-100.

Berinsky, Adam J. and Gabriel S. Lenz (2011). "Education and Political Participation: Exploring the Causal Link”. In: Political Behavior 33.3, pp. 357-373.

Bernstein, Robert, Anita Chadha, and Robert Montjoy (2001). "Overreporting Voting:

Why It Happens and Why It Matters”. In: Public Opinion Quarterly 65.1, pp. 22-44. 
Bhatti, Yosef, Jens Olav Dahlgaard, Jonas Hedegaard Hansen, and Kasper M Hansen (2018). "Core and Peripheral Voters: Predictors of Turnout Across Three Types of Elections". In: Political Studies.

Bhatti, Yosef, Jens Olav Dahlgaard, Jonas Hedegaard Hansen, and Kasper M. Hansen (2016). "Is Door-to-Door Canvassing Effective in Europe? Evidence from a MetaStudy across Six European Countries”. In: British Journal of Political Science, pp. 112.

- (2017a). "How Voter Mobilization from Short Text Messages Travels within Households and Families: Evidence from Two Nationwide Field Experiments”. In: Electoral Studies 50, pp. 39-49.

- (2017b). "Moving the Campaign from the Front Door to the Front Pocket: Field Experimental Evidence on the Effect of Phrasing and Timing of Text Messages on Voter Turnout”. In: Journal of Elections, Public Opinion and Parties, pp. 1-2o.

Bhatti, Yosef, Edward Fieldhouse, and Kasper M. Hansen (2018). "It's a Group Thing: How Voters Go to the Polls Together". In: Political Behavior.

Bhatti, Yosef and Kasper M. Hansen (2012a). "Leaving the Nest and the Social Act of Voting: Turnout among First-Time Voters”. In: Journal of Elections, Public Opinion es Parties 22.4, pp. 380-406.

- (2012b). "Retiring from Voting: Turnout among Senior Voters". In: Journal of Elections, Public Opinion es Parties 22.4, pp. 479-500.

Bhatti, Yosef, Kasper M. Hansen, and Hanna Wass (2012). "The Relationship between Age and Turnout: A Roller-Coaster Ride”. In: Electoral Studies 31.3, pp. 588-593.

- (2016). "First-Time Boost Beats Experience: The Effect of Past Eligibility on Turnout”. In: Electoral Studies 41, pp. 151-158.

Blais, André (2000). To Vote or Not to Vote: The Merits and Limits of Rational Choice Theory. Pittsburgh, Pa.: University of Pittsburgh Press.

- (2006). "What Affects Voter Turnout?" In: Annual Review of Political Science 9.1, pp. 111-125.

- (2007). "Turnout in Elections". In: The Oxford Handbook of Political Behavior. Ed. by Russell J. Dalton and Hans-Dieter Klingemann. Oxford: Oxford University Press, pp. 621-635.

Blais, André and Kees Aarts (2006). "Electoral Systems and Turnout”. In: Acta Politica 41.2, pp. $180-196$.

Blais, André and Agnieszka Dobrzynska (1998). “Turnout in Electoral Democracies”. In: European Journal of Political Research 33.2, pp. 239-261.

Blais, André and Daniel Rubenson (2013). "The Source of Turnout Decline: New Values or New Contexts?" In: Comparative Political Studies 46.1, pp. 95-117.

Bond, Robert M., Christopher J. Fariss, Jason J. Jones, Adam D. I. Kramer, Cameron Marlow, Jaime E. Settle, and James H. Fowler (2012). "A 61-Million-Person Experiment in Social Influence and Political Mobilization”. In: Nature 489, p. 295.

Borge, Julie Ane Ødegaard (2016). "Creating Democratic Citizens? An Analysis of Mock Elections as Political Education in School”. Ph.D. Bergen: University of Bergen. 
- (2017). "Tuning in to Formal Politics: Mock Elections at School and the Intention of Electoral Participation among First Time Voters in Norway”. In: Politics 37.2, pp. 201-214.

Brady, Henry E., Kay Lehman Schlozman, and Sidney Verba (2015). "Political Mobility and Political Reproduction from Generation to Generation”. In: The ANNALS of the American Academy of Political and Social Science 657.1, pp. 149-173.

Brody, Richard A. and Paul M. Sniderman (1977). "From Life Space to Polling Place: The Relevance of Personal Concerns for Voting Behavior”. In: British Journal of Political Science 7.3, pp. 337-360.

Butler, David and Donald Stokes [1971] (1974). Political Change in Britain: The Evolution of Electoral Choice. 2nd ed. London: Macmillan.

Campbell, Angus, Philip E. Converse, Warren E. Miller, and Donald E. Stokes [1960] (1980). The American Voter. unabridged version. Chicago Ill.: University Of Chicago Press.

Cancela, João and Benny Geys (2016). "Explaining Voter Turnout: A Meta-Analysis of National and Subnational Elections". In: Electoral Studies 42, pp. 264-275.

Carey, John M. and Yusaku Horiuchi (2017). "Compulsory Voting and Income Inequality: Evidence for Lijphart's Proposition from Venezuela”. In: Latin American Politics and Society 59.2, pp. 122-144.

Cebula, Richard J. (2017). “Unemployment and Voter Turnout Revisited: A Brief Note”. In: Electoral Studies 48, pp. 149-152.

Chan, Tak Wing and Matthew Clayton (2006). "Should the Voting Age Be Lowered to Sixteen? Normative and Empirical Considerations". In: Political Studies 54.3, pp. 533$55^{8 .}$

Coppock, Alexander and Donald P. Green (2016). "Is Voting Habit Forming? New Evidence from Experiments and Regression Discontinuities". In: American Journal of Political Science 60.4, pp. 1044-1062.

Cutts, David, Edward Fieldhouse, and Peter John (2009). "Is Voting Habit Forming? The Longitudinal Impact of a GOTV Campaign in the UK”. In: Journal of Elections, Public Opinion and Parties 19.3, pp. 251-263.

De Leeuw, Edith and Wim de Heer (2002). "Trends in Household Survey Nonresponse: A Longitudinal and International Perspective". In: Survey Nonresponse. Ed. by Robert M. Groves, Don A. Dillman, John L. Eltinge, and Roderick J.A. Little. New York: Wiley.

Denny, Kevin and Orla Doyle (2009). "Does Voting History Matter? Analysing Persistence in Turnout”. In: American Journal of Political Science 53.1, pp. 17-35.

Dinas, Elias (2012). “The Formation of Voting Habits”. In:Journal of Elections, Public Opinion er Parties 22.4, pp. 431-456.

Downs, Anthony (1957). An Economic Theory of Democracy. New York: Harper \& Row.

Elmquist, Tobias and Annika Bergström (2012). "Samhälle Opinion Media - Västra Götaland 2010”. In: Västsvensk vardag. Ed. by Annika Bergström. 53. Gothenburg: SOM Institute.

European Parliament (2015). Reform of the Electoral Law of the European Union $(2015 / 2035(I N L))$. 
Finseraas, Henning and Kåre Vernby (2014). "A Mixed Blessing for the Left? Early Voting, Turnout and Election Outcomes in Norway”. In: Electoral Studies 33, pp. 278-291.

Fisher, Ronald A. (1935). The Design of Experiments. Edinburgh: Oliver and Boyd.

Fowler, Anthony (2013). "Electoral and Policy Consequences of Voter Turnout: Evidence from Compulsory Voting in Australia”. In: Quarterly Journal of Political Science 8.2, pp. 159-182.

Franklin, Mark N. (2004). Voter Turnout and the Dynamics of Electoral Competition in Established Democracies since 1945. Cambridge: Cambridge University Press.

Franklin, Mark N. and Sara B. Hobolt (2011). "The Legacy of Lethargy: How Elections to the European Parliament Depress Turnout”. In: Electoral Studies 30.1, pp. 67-76.

Frödin Gruneau, Moa (2018). “Reconsidering the Partner Effect on Voting”. In: Electoral Studies 53, pp. 48-56.

Fullmer, Elliott B. (2015). “Early Voting: Do More Sites Lead to Higher Turnout?” In: Election Law Journal 14.2, pp. 81-96.

Gäbler, Stefanie, Niklas Potrafke, and Felix Rösel (2017). Compulsory Voting, Voter Turnout and Asymmetrical Habit-Formation. CESinfo working papers 6764 . München.

Garmann, Sebastian (2017). "The Effect of a Reduction in the Opening Hours of Polling Stations on Turnout". In: Public Choice 171.1-2, pp. 99-117.

Gerber, Alan S. and Donald P. Green (2000). "The Effects of Canvassing, Telephone Calls, and Direct Mail on Voter Turnout: A Field Experiment”. In: The American Political Science Review 94.3, pp. 653-663.

Gerber, Alan S., Donald P. Green, and Christopher W. Larimer (2008). "Social Pressure and Voter Turnout: Evidence from a Large-Scale Field Experiment”. In: American Political Science Review 102.01.

Gerber, Alan S., Donald P. Green, and Ron Shachar (2003). "Voting May Be HabitForming: Evidence from a Randomized Field Experiment”. In: American Journal of Political Science 47.3, pp. 540-550.

Gerber, Alan S., Jonathan Gruber, and Daniel M. Hungerman (2016). "Does Church Attendance Cause People to Vote? Using Blue Laws' Repeal to Estimate the Effect of Religiosity on Voter Turnout”. In: British Journal of Political Science 46.3, pp. 481-500.

Gerber, Alan S., Gregory A. Huber, David Doherty, and Conor M. Dowling (2016). "Why People Vote: Estimating the Social Returns to Voting”. In: British Journal of Political Science 46.2, pp. 241-264.

Gerber, Alan S. and Todd Rogers (2009). "Descriptive Social Norms and Motivation to Vote: Everybody's Voting and so Should You”. In: The Journal of Politics 71.1, pp. 178191.

Gidengil, Elisabeth, Hanna Wass, and Maria Valaste (2016). "Political Socialization and Voting: The Parent-Child Link in Turnout”. In: Political Research Quarterly 69.2, pp. 373-383.

Gosnell, Harold F. (1927). Getting Out the Vote: An Experiment in the Stimulation of Voting. Chicago Ill.: University of Chicago Press.

Granberg, Donald and Sören Holmberg (1991). "Self-Reported Turnout and Voter Validation”. In: American Journal of Political Science 35.2, p. 448. 
Green, Donald P., Alan S. Gerber, and David W. Nickerson (2003). "Getting out the Vote in Local Elections: Results from Six Door-to-Door Canvassing Experiments”. In: Journal of Politics 65.4, pp. 1083-1096.

Green, Donald P., Mary C. McGrath, and Peter M. Aronow (2013). "Field Experiments and the Study of Voter Turnout". In: Journal of Elections, Public Opinion and Parties 23.1, pp. 27-48.

Green, Donald P. and Ron Shachar (2000). "Habit Formation and Political Behaviour: Evidence of Consuetude in Voter Turnout”. In: British Journal of Political Science 30.4, pp. 561-573.

Groves, Robert M. and Mick P. Couper (1998). Nonresponse in Household Interview Surveys. New York: Wiley.

Groves, Robert M., Don A. Dillman, John L. Eltinge, and Roderick J.A. Little (2002). Survey Nonresponse. New York: Wiley.

Groves, Robert M. and Emilia Peytchev (2008). “The Impact of Nonresponse Rates on Nonresponse Bias: A Meta-Analysis”. In: Public Opinion Quarterly 72.2, pp. 167-189.

Hajnal, Zoltan and Jessica Trounstine (2005). "Where Turnout Matters: The Consequences of Uneven Turnout in City Politics". In: The Journal of Politics 67.2, pp. 515535 .

Hansen, Jonas Hedegaard (2017). Skolevalg 2017. Undersøgelse af elevernes oplevelse med og udbytte af Skolevalg 2017. 2017/2. Copenhagen: University of Copenhagen.

Hansen, Jonas Hedegaard, Kasper Møller Hansen, and Klaus Levinsen (2015). Skolevalg 2015. En kvantitativ evaluering af elevernes oplevelse og udbytte af Skolevalg. WorkingPaper. Center for Valg og Partier, Institut for Statskundskab, Københavns Universitet, pp. 1-71.

Hart, Daniel and Robert Atkins (2011). "American Sixteen- and Seventeen-Year-Olds Are Ready to Vote". In: The Annals of the American Academy of Political and Social Science 633, pp. 201-222.

Hedström, Peter (2005). Dissecting the Social: On the Principles of Analytical Sociology. Cambridge: Cambridge University Press.

Highton, Benjamin (1997). “Easy Registration and Voter Turnout”. In: The Journal of Politics 59.2, pp. 565-575.

- (200o). "Residential Mobility, Community Mobility, and Electoral Participation”. In: Political Behavior 22.2, pp. 109-120.

- (2004). "Voter Registration and Turnout in the United States". In: Perspectives on Politics 2.3, pp. 507-515.

Highton, Benjamin and Raymond E. Wolfinger (2001). "The First Seven Years of the Political Life Cycle”. In: American Journal of Political Science 45.1, pp. 202-209.

Hix, Simon and Michael Marsh (2011). "Second-Order Effects plus Pan-European Political Swings: An Analysis of European Parliament Elections across Time”. In: Electoral Studies 30.1, pp. 4-15.

Hobbs, William R., Nicholas A. Christakis, and James H. Fowler (2014). "Widowhood Effects in Voter Participation”. In: American Journal of Political Science 58.1, pp. 1-16.

Holmberg, Sören and Henrik Oscarsson (2004). Väljare: svenskt väljarbeteende under 50 år. Stockholm: Norstedts Juridik AB. 
Huckfeldt, R. Robert (1979). "Political Participation and the Neighborhood Social Context”. In: American Journal of Political Science 23.3, pp. 579-592.

Huckfeldt, Robert and John Sprague (1992). "Political Parties and Electoral Mobilization: Political Structure, Social Structure, and the Party Canvass". In: The American Political Science Review 86.1, pp. 70-86.

Igielnik, Ruth, Scott Keeter, Courtney Kennedy, and Bradley Spahn (2018). Commercial Voter Files and the Study of U.S. Politics. Washington, D.C.: Pew Research Center.

Jennings, M. Kent, Laura Stoker, and Jake Bowers (2009). "Politics across Generations: Family Transmission Reexamined”. In: The Journal of Politics 71.3, pp. 782-799.

Katosh, John P. and Michael W. Traugott (1981). "The Consequences of Validated and Self-Reported Voting Measures”. In: Public Opinion Quarterly 45.4, pp. 519-535.

Key Jr, V. O. (1966). The Responsible Electorate : Rationality in Presidential Voting, 1936-1960. New York: Vintage Books.

Key Jr., V. O. and Frank Munger (1959). "Social Determinism and Electoral Decision: The Case of Indiana”. In: American Voting Behavior. Ed. by Eugene Burdick and Arthur J. Brodbeck. Glencoe, Ill.: The Free Press, pp. 281-299.

Konzelmann, Laura, Corina Wagner, and Hans Rattinger (2012). "Turnout in Germany in the Course of Time: Life Cycle and Cohort Effects on Electoral Turnout from 1953 to 2049 ". In: Electoral Studies 31.2, pp. 250-261.

Leighley, Jan E. and Jonathan Nagler (2014). Who Votes Now?: Demographics, Issues, Inequality, and Turnout in the United States. Princeton: Princeton University Press.

Lewis-Beck, Michael S., Helmut Norpoth, William G. Jacoby, and Herbert F. Weisberg (2008). The American Voter Revisited. Ann Arbor: University of Michigan Press.

Lijphart, Arend (1997). “Unequal Participation: Democracy's Unresolved Dilemma”. In: The American Political Science Review 91.1, pp. 1-14.

Lindgren, Karl-Oskar, Sven Oskarsson, and Mikael Persson (2017). Can Increased Education Help Reduce the Political Opportunity Gap? Working Paper 2017:12. Uppsala: Institute for Evaluation of Labour Market and Education Policy.

Lisa, Schur, Ameri Mason, and Adya Meera (2017). "Disability, Voter Turnout, and Polling Place Accessibility”. In: Social Science Quarterly 98.5, pp. 1374-1390.

Massey, Douglas S., Roger Tourangeau, J. Michael Brick, and Douglas Williams (2013). "Explaining Rising Nonresponse Rates in Cross-Sectional Surveys". In: The ANNALS of the American Academy of Political and Social Science 645.1, pp. 36-59.

McAllister, Ian (2014). "The Politics of Lowering the Voting Age in Australia: Evaluating the Evidence”. In: Australian Journal of Political Science 49.1, pp. 68-83.

Meredith, Marc (2009). "Persistence in Political Participation”. In: Quarterly Journal of Political Science 4.3, pp. 187-209.

Meyer, Bruce D., Wallace K. C. Mok, and James X. Sullivan (2015). "Household Surveys in Crisis”. In: Journal of Economic Perspectives 29.4, pp. 199-226.

Milbrath, Lester W. (1965). Political Participation: How and Why Do People Get Involved in Politics. Chicago.

Morgan, Stephen L. and Christopher Winship (2014). Counterfactuals and Causal Inference: Methods and Principles for Social Research. 2 edition. New York, NY: Cambridge University Press. 
Nickerson, David W. (2007). "Quality Is Job One: Professional and Volunteer Voter Mobilization Calls”. In: American Journal of Political Science 51.2, pp. 269-282.

- (2008). "Is Voting Contagious? Evidence from Two Field Experiments". In: The American Political Science Review 102.1, pp. 49-57.

Nie, Norman H., Jane Junn, and Kenneth Stehlik-Barry (1996). Education and Democratic Citizenship in America. University of Chicago Press.

Nyman, Pär (2017). "Door-to-Door Canvassing in the European Elections: Evidence from a Swedish Field Experiment”. In: Electoral Studies 45, pp. 110-118.

Öhrvall, Richard (2009). Valdeltagande bland förstagångsväljare. Stockholm: Swedish Association of Local Authorities and Regions.

- (2012). Svenskt valdeltagande under hundra år. 13. Stockholm: Statistics Sweden.

- (2015). "Voter Turnout". In: The Oxford Handbook of Swedish Politics. Ed. by Jon Pierre. Oxford: Oxford University Press, pp. 229-245.

- (2018a). "First Time Fades Away: Effects of European Parliament Elections on National Turnout”. In: Unpublished manuscript.

- (2018b). "Groving into Voting: The First Election Experience and Habit Formation”. In: Unpublished manuscript.

Öhrvall, Richard and Sven Oskarsson (2018). "Practice Makes Voters? Effects of Student Mock Elections on Turnout”. In: Unpublished manuscript.

Persson, Mikael (2014). "Testing the Relationship Between Education and Political Participation Using the 1970 British Cohort Study”. In: Political Behavior 36.4, pp. 877897.

- (2015). "Education and Political Participation". In: British Journal of Political Science 45.03, pp. 689-703.

Persson, Mikael, Maria Solevid, and Richard Öhrvall (2013). "Voter Turnout and Political Equality: Testing the 'Law of Dispersion' in a Swedish Natural Experiment”. In: Politics 33.3, pp. 172-184.

Plutzer, Eric (2002). "Becoming a Habitual Voter: Inertia, Resources, and Growth in Young Adulthood”. In: American Political Science Review 96.1, pp. 41-56.

Powell, G. Bingham (1986). “American Voter Turnout in Comparative Perspective”. In: The American Political Science Review 80.1, pp. 17-43.

Putnam, Robert (2000). Bowling Alone: The Collapse and Revival of American Community. New York, NY: Simon \& Schuster.

Putnam, Robert D., Robert Leonardi, and Raffaella Y. Nonetti (1993). Making Democracy Work: Civic Traditions in Modern Italy. Princeton University Press.

Reif, Karlheinz and Hermann Schmitt (1980). "Nine Second-Order National Elections: A Conceptual Framework for the Analysis of European Election Results". In: European journal of political research 8.1, pp. 3-44.

Riker, William H. and Peter C. Ordeshook (1968). "A Theory of the Calculus of Voting”. In: American Political Science Review 62.01, pp. 25-42.

Rogers, Todd, Craig R. Fox, and Alan S. Gerber (2013). "Rethinking Why People Vote: Voting as Dynamic Social Expression”. In: The Behavioral Foundations of Public Policy. Ed. by Eldar Shafir. Vol. 91. Princeton, N.J.: Princeton University Press. 
Rogers, Todd, Donald P. Green, John Ternovski, and Carolina Ferrerosa Young (2017). "Social Pressure and Voting: A Field Experiment Conducted in a High-Salience Election”. In: Electoral Studies 46, pp. 87-100.

Rolfe, Meredith (2013). Voter Turnout: A Social Theory of Political Participation. Reprint edition. Cambridge: Cambridge University Press.

Rosenbaum, Paul R. (2010). Design of Observational Studies. New York, NY: SpringerVerlag.

Rosenstone, Steven J. and John Mark Hansen (1993). Mobilization, Participation, and Democracy in America. Macmillan Publishing Company.

Rosenstone, Steven J. and Raymond E. Wolfinger (1978). "The Effect of Registration Laws on Voter Turnout”. In: The American Political Science Review 72.1, pp. 22-45.

Schlozman, Kay Lehman, Sidney Verba, and Henry E. Brady (2012). The Unheavenly Chorus : Unequal Political Voice and the Broken Promise of American Democracy. Princeton, N.J. ; Princeton University Press.

Sinclair, Betsy (2012). The Social Citizen: Peer Networks and Political Behavior. Chicago Studies in American Politics edition. Chicago: University of Chicago Press.

Singh, Shane P. (2018). "Compulsory Voting and Dissatisfaction with Democracy”. In: British Journal of Political Science 48.3, pp. 843-854.

Sinnott, Richard and Christopher H Achen (2008). "Voter Dropoff in Low-Salience Elections”. Working paper. Working paper.

Smets, Kaat (2012). "A Widening Generational Divide? The Age Gap in Voter Turnout Through Time and Space”. In: Journal of Elections, Public Opinion es Parties 22.4, pp. 407-430.

- (2016). "Revisiting the Political Life-Cycle Model: Later Maturation and Turnout Decline among Young Adults". In: European Political Science Review 8.2, pp. 225-249.

Smets, Kaat and Carolien van Ham (2013). "The Embarrassment of Riches? A MetaAnalysis of Individual-Level Research on Voter Turnout”. In: Electoral Studies 32.2, pp. 344-359.

Solijonov, Abdurashid (2016). Voter Turnout Trends around the World. Stockholm: IDEA. SOU (2016). Lat fler forma framtiden! Statens offentliga utredningar 2016:5. Stockholm: Wolters Kluwer.

Squire, Peverill, Raymond E. Wolfinger, and David P. Glass (1987). "Residential Mobility and Voter Turnout”. In: The American Political Science Review 81.1, pp. 45-65.

Stockemer, Daniel (2017). "What Affects Voter Turnout? A Review Article/MetaAnalysis of Aggregate Research”. In: Government and Opposition 52.4, pp. 698-722.

Stoker, Laura and M. Kent Jennings (1995). "Life-Cycle Transitions and Political Participation: The Case of Marriage”. In: The American Political Science Review 89.2, pp. 421433 .

Tajfel, Henri (1974). "Social Identity and Intergroup Behaviour”. In: Information (International Social Science Council) 13.2, pp. 65-93.

Tingsten, Herbert (1937). Political Behavior. London: P. S. King \& Son.

Tullock, Gordon (1967). Toward a Mathematics of Politics. Ann Arbor: University of Michigan Press. 
Verba, Sidney (2003). "Would the Dream of Political Equality Turn out to Be a Nightmare?" In: Perspectives on Politics 1.04.

Verba, Sidney, Nancy Burns, and Kay Lehman Schlozman (2003). "Unequal at the Starting Line: Creating Participatory Inequalities across Generations and among Groups”. In: The American Sociologist 34.1-2, pp. 45-69.

Verba, Sidney and Norman H. Nie (1972). Participation in America: Political Democracy and Social Equality. New York: Harper and Row.

Verba, Sidney, Norman H. Nie, and Jae-On Kim (1978). Participation and Political Equality: A Seven-Nation Comparison. Cambridge: Cambridge U.P.

Verba, Sidney, Kay Lehman Schlozman, and Henry E. Brady (1995). Voice and Equality: Civic Voluntarism in American Politics. Cambridge, Mass.: Harvard University Press.

Vernersdotter, Frida and Lisa Kareliusson (2012). "Omval-SOM-undersökningen 201". In: Omstritt omval. Ed. by Linda Berg and Henrik Oscarsson. 55. Gothenburg: SOM Institute, p. 15 .

Wagner, Markus, David Johann, and Sylvia Kritzinger (2012). "Voting at 16: Turnout and the Quality of Vote Choice”. In: Electoral Studies 31.2, pp. 372-383.

Westholm, Anders (1999). "The Perceptual Pathway: Tracing the Mechanisms of Political Value Transfer across Generations”. In: Political Psychology 20.3, pp. 525-551.

Williams, Douglas and J. Michael Brick (2018). "Trends in U.S. Face-To-Face Household Survey Nonresponse and Level of Effort”. In: Journal of Survey Statistics and Methodology 6.2, pp. 186-211.

Wolfinger, Nicholas H. and Raymond E. Wolfinger (2008). "Family Structure and Voter Turnout”. In: Social forces 86.4, pp. 1513-1528.

Wolfinger, Raymond E. and Steven J. Rosenstone (1980). Who Votes? New Haven: Yale U.P.

Wood, Wendy and David T. Neal (2007). "A New Look at Habits and the Habit-Goal Interface.” In: Psychological Review 114.4, pp. 843-863.

Zeglovits, Eva and Julian Aichholzer (2014). "Are People More Inclined to Vote at 16 than at 18? Evidence for the First-Time Voting Boost Among 16- to 25-Year-Olds in Austria”. In: Journal of Elections, Public Opinion and Parties 24.3, pp. 351-361.

Zuckerman, Alan S. (2005). The Social Logic of Politics: Personal Networks as Contexts for Political Behavior. Temple University Press. 


\section{Essays}

The essays associated with this thesis have been removed for copyright reasons. For more details about these see:

http://urn.kb.se/resolve?urn=urn:nbn:se:liu:diva-150169 